\title{
Heme cytotoxicity and the pathogenesis of immune-mediated inflammatory diseases
}

\section{Rasmus Larsen, Zélia Gouveia, Miguel P. Soares and Raffaella Gozzelino*}

Instituto Gulbenkian de Ciência, Oeiras, Portugal

\section{Edited by:}

Jaime Kapitulnik, The Hebrew

University of Jerusalem, Israel

\section{Reviewed by:}

Stefan W. Ryter, Harvard Medical

School, USA

Stephan Immenschuh, Hannover

Medical School, Germany

*Correspondence:

Raffaella Gozzelino, Instituto

Gulbenkian de Ciência, Rua da Quinta

Grande, 6, 2780-156 Oeiras, Portugal. e-mail: rgozzelino@igc.gulbenkian.pt
Heme, iron ( $\mathrm{Fe}$ ) protoporphyrin IX, functions as a prosthetic group in a range of hemoproteins essential to support life under aerobic conditions. The Fe contained within the prosthetic heme groups of these hemoproteins can catalyze the production of reactive oxygen species. Presumably for this reason, heme must be sequestered within those hemoproteins, thereby shielding the reactivity of its Fe-heme. However, under pathologic conditions associated with oxidative stress, some hemoproteins can release their prosthetic heme groups. While this heme is not necessarily damaging per se, it becomes highly cytotoxic in the presence of a range of inflammatory mediators such as tumor necrosis factor. This can lead to tissue damage and, as such, exacerbate the pathologic outcome of several immune-mediated inflammatory conditions. Presumably, targeting "free heme" may be used as a therapeutic intervention against these diseases.

Keywords: heme, heme oxygenase, cytotoxicity, programmed cell death, immune-mediated inflammatory diseases

\section{PHYSIOLOGICAL ROLE OF HEME}

Heme acts as prosthetic group in a range of hemoproteins that play a pivotal role in many essential biological processes. These include gas transport and storage, mitochondrial electron transport chain, drug metabolism, signal transduction and regulation of gene expression (Chapman et al., 1997).

\section{STRUCTURE AND BIOCHEMISTRY OF HEME}

Heme is a hydrophobic metallo-compound containing a $\mathrm{Fe}$ atom within its protoporphyrin ring. It is composed of four methanebridged pyrroles (tetrapyrrole ring) bound to the central $\mathrm{Fe}$ atom through nitrogen atoms (Reedy and Gibney, 2004; Kumar and Bandyopadhyay, 2005; Tsiftsoglou et al., 2006). Ferrous (Fe $\left.{ }^{2+}\right)$ heme has a neutral chemical charge, whereas ferric $\left(\mathrm{Fe}^{3+}\right)$ heme is positively charged, and can bind anions (Kumar and Bandyopadhyay, 2005). Although ferrous and ferric states are the most common within the heme structure, oxidative states of Fe-heme can vary from $\mathrm{Fe}^{2+}$ to $\mathrm{Fe}^{5+}$ (Ogura et al., 1996; Karpefors et al., 2000; Dey and Ghosh, 2002).

Heme exists mainly as $a, b$, and $c$ variants, which differ by subtle chemical modifications (Chapman et al., 1997; Tsiftsoglou et al., 2006; Smith et al., 2010). One of the vinyl groups of heme $b$, is replaced by a 17-hydroxyethylfarnesyl group in heme $a$. One of the methyl groups of heme $b$ is also replaced by a formyl group in heme $a$ (Caughey et al., 1975; Han et al., 1991). In heme $c$, both vinyl groups of heme $b$ are replaced by sulfhydryl groups (Bowman and Bren, 2008). Heme $b$ is the most common variant in mammals, present, among others, in hemoglobin ( $\mathrm{Hb})$ and myoglobin (Fermi et al., 1984; Evans and Brayer, 1990; Paoli et al., 1996; Park et al., 2006). Heme $a$ and $c$ are found in cytochrome $c$ oxidase and cytochrome $c$, respectively (Bushnell et al., 1990; Tsukihara et al., 1995). Whereas heme $c$ can bind covalently to proteins, via two thioether bonds, this is not the case for heme $b$ and $a$, eventually allowing for their release from hemoproteins (Allen et al., 2003).

\section{HEMOPROTEINS}

Hemoproteins have a diverse spectrum of biological functions. These include transport and storage of diatomic gaseous molecules such as oxygen $\left(\mathrm{O}_{2}\right)$, nitric oxide $(\mathrm{NO})$ and carbon monoxide (CO; Chay and Brillhart, 1974a,b; Aono, 2008; Kakar et al., 2010). They are also essential for electron transfer reactions (Makinen et al., 1983; Gray and Winkler, 1996) as well as for modulation of gene transcription (Tahara et al., 2004a,b; Youn et al., 2006; Hira et al., 2007), such as involved in the regulation of circadian rhythms (Kaasik and Lee, 2004). Prosthetic heme groups have also been implicated in the regulation of signal transduction pathways (Igarashi and Sun, 2006; Zenke-Kawasaki et al., 2007), ion-channel functions (Tang et al., 2003; Horrigan et al., 2005), micro-RNA processing (Faller et al., 2007) and the metabolism of xenobiotics and drugs (Bernhardt, 1996; Rowland et al., 2006).

Under physiologic conditions, heme is found mainly in the "heme pockets" of hemoproteins. These are characterized by a high frequency in aromatic amino acids (Table 1), such as phenylalanine $(\mathrm{F})$, tyrosine $(\mathrm{Y})$ or tryptophan $(\mathrm{W})$ and by few or no charged amino acids (Li et al., 2011), conferring the hydrophobicity required to promote stable heme binding to hemoproteins. Five highly conserved amino acids, including histidine $(\mathrm{H})$, methionine $(\mathrm{M})$, cysteine $(\mathrm{C})$, tyrosine $(\mathrm{Y})$ and lysine $(\mathrm{K})$ can act as axial heme ligands in the heme pockets of hemoproteins ( $\mathrm{Li}$ et al., 2011). Of these, $\mathrm{H}$ is frequently found in hemoproteins containing heme $c$ or $b$ (Table 1). Moreover, $\mathrm{C}$ often promotes binding of heme $b$, whereas M binds heme $c$ (Fufezan et al., 2008; Li et al., 2011; Table 1). Other hydrophobic amino acids such as leucine $(\mathrm{L})$, isoleucine $(\mathrm{I})$ and valine $(\mathrm{V})$ can also create interactions with the porphyrin structure of heme, whereas arginine $(\mathrm{R})$ and other 
Table 1 | Selected representatives of Mammalian hemoproteins and heme-sensing proteins.

\begin{tabular}{|c|c|c|c|c|}
\hline Function & Representative hemoprotein & Number/type of heme & Axial ligand & References \\
\hline \multirow[t]{4}{*}{ Electron transport } & Cytochrome c & 1/c-type & His, Met & Mirkin et al. (2008) \\
\hline & Cytochrome b5 & 1/b-type & His, His & Wirtz et al. (2000) \\
\hline & Cytochrome c oxidase & 2/a-type & His/Nacant, His/His & Tsukihara et al. (1995) \\
\hline & Cytochrome c reductase & 2/b-type, 1/c-type & His/His, His/His, His/Met & Xia et al. (1997); Zhang et al. (1998) \\
\hline \multirow[t]{2}{*}{ Gas carriers } & Hemoglobin & 4/b-type & His, Vacant & Park et al. (2006) \\
\hline & Myoglobin & 1/b-type & His, Vacant & $\begin{array}{l}\text { Evans and Brayer (1988); Vojtechovsky } \\
\text { et al. (1999) }\end{array}$ \\
\hline Catalytic & Catalase I & 1/b-type & Tyr, Vacant & Putnam et al. (2000) \\
\hline \multirow[t]{5}{*}{ activity - enzyme } & Cytochrome P450 & 1/b-type & Cys, Vacant or water & Rowland et al. (2006) \\
\hline & Indoleamine 2,3-dioxygenase & 1/b-type & His, ligand & Sugimoto et al. (2006) \\
\hline & NO synthase & 2/b-type & Cys, Vacant & Crane et al. (1997) \\
\hline & Cystathionine $\beta$-synthase & 1/b-type & Cys/His & Meier et al. (2001) \\
\hline & Tryptophan 2,3-dioxygenase & 4/b-type & His/Vacant & Zhang et al. (2007b) \\
\hline Transient heme & Heme oxygenase & 1/b-type & His, Water & Lad et al. (2003) \\
\hline \multirow[t]{2}{*}{ binding } & Hemopexin & 1/b-type & His/His & Paoli et al. (1999) \\
\hline & Albumin & 1/b-type & Tyr/Nacant & Wardell et al. (2002) \\
\hline Heme-sensing/ & NPAS2 & 2/b-type & His/Cys or His/His, His/? & Dioum et al. (2002); Uchida et al. (2005) \\
\hline \multirow[t]{2}{*}{ heme regulated } & Iron regulatory protein 2 (IRP2) & 1 & Cys/? & Jeong et al. (2004) \\
\hline & Soluble guanylyl cyclase & 1/b-type & His/Vacant & Ma et al. (2007) \\
\hline
\end{tabular}

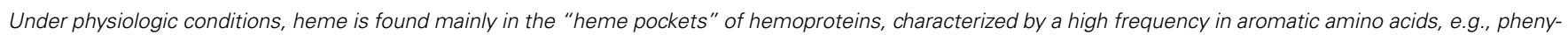

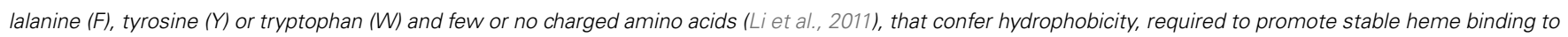

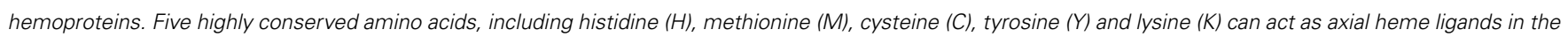

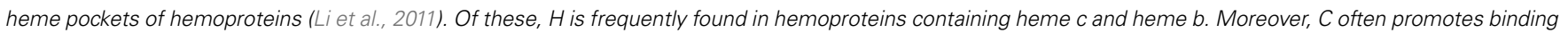

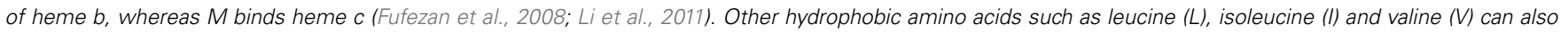

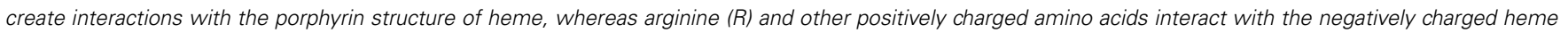
proprionate groups (Schneider et al., 2007).

positively charged amino acids can interact with the negatively charged heme propionate groups (Schneider et al., 2007).

Several heme-binding motifs have been described, namely $\mathrm{CXXCH}$ and CXXCK that bind primarily heme $c$ and in which "X" refers to any amino acid (Fufezan et al., 2008; Smith et al., 2010; Li et al., 2011). The GX[HR]XC[PLAV]G heme-binding motif is associated mainly with heme $b$ (Li et al., 2011). Another related FXXGXXCXG motif found in mammal, cytochrome P450, as well as in plant and bacterial hemoproteins binds to heme $b$ (Li et al., 2011). Other heme-binding motifs can be formed by only two amino acids (such as the CP motif; Li et al., 2011).

In some hemoproteins, the $\mathrm{Fe}$ and the protoporphyrin IX ring of heme can undergo chemical and/or electronic modifications, such as demonstrated for peroxidases in which heme uses hydrogen peroxide $\left(\mathrm{H}_{2} \mathrm{O}_{2}\right)$ to undergo several $\mathrm{Fe}$ oxidoreductase cycles associated with conformational alterations of its protoporphyrin ring. This can lead to the oxidation of neighboring molecules, e.g., indoles, phenols, aromatic amines, lignin, $\mathrm{Mn}^{2+}$ ions, halide ions or proteins (Badyal et al., 2006; Zederbauer et al., 2007; Battistuzzi et al., 2010). In other hemoproteins, heme does not undergo alterations in its $\mathrm{Fe}$ redox state or protoporphyrin conformation (Poulos, 2007). This is the case for hemoproteins that bind gaseous molecules such as guanylate cyclase, $\mathrm{Hb}$, myoglobin or the transcription factor neuronal PAS domain-containing protein 2 (NPAS2), among others (Chay and Brillhart, 1974a,b; Dioum et al., 2002; Podstawka and Proniewicz, 2004; Uchida et al., 2005).
Binding of NO or CO to these hemoproteins modulates their biologic activity, e.g., increased production of cGMP in the case of guanylate cyclase (Ma et al., 2007), regulation of $\mathrm{O}_{2}$ transport in the case of $\mathrm{Hb}$ or gene transcription in the case of $\mathrm{CO}$ binding to NPAS2 (Dioum et al., 2002). In other instances, biologic activity is regulated by heme binding itself, as it is the case for the transcriptional repressor Bach1 (Tahara et al., 2004a,b; Hira et al., 2007).

\section{HEME METABOLISM}

Heme intracellular content must be tightly controlled to prevent heme-driven cytotoxicity while assuring that heme is available to be incorporated into nascent apo-hemoproteins. This is particularly relevant for cells with very high hemoprotein content such as erythroid or muscle cells expressing $\mathrm{Hb}$ and myoglobin, respectively. This regulatory mechanism is ensured largely through control of heme synthesis, transport and catabolism.

\section{HEME SYNTHESIS}

Heme de novo synthesis occurs through a sequence of eight enzymatic steps, four of which take place in the cytoplasm and four in the mitochondria (Figure 1; Heinemann et al., 2008). The first and rate-limiting step is catalyzed in the mitochondria by $\delta$-amino levulinic acid (ALA) synthase (ALAS), an enzyme that converts glycine and succinyl-CoA into ALA. In most cells, heme synthesis is down-regulated by heme, via inhibition of ALAS mRNA 


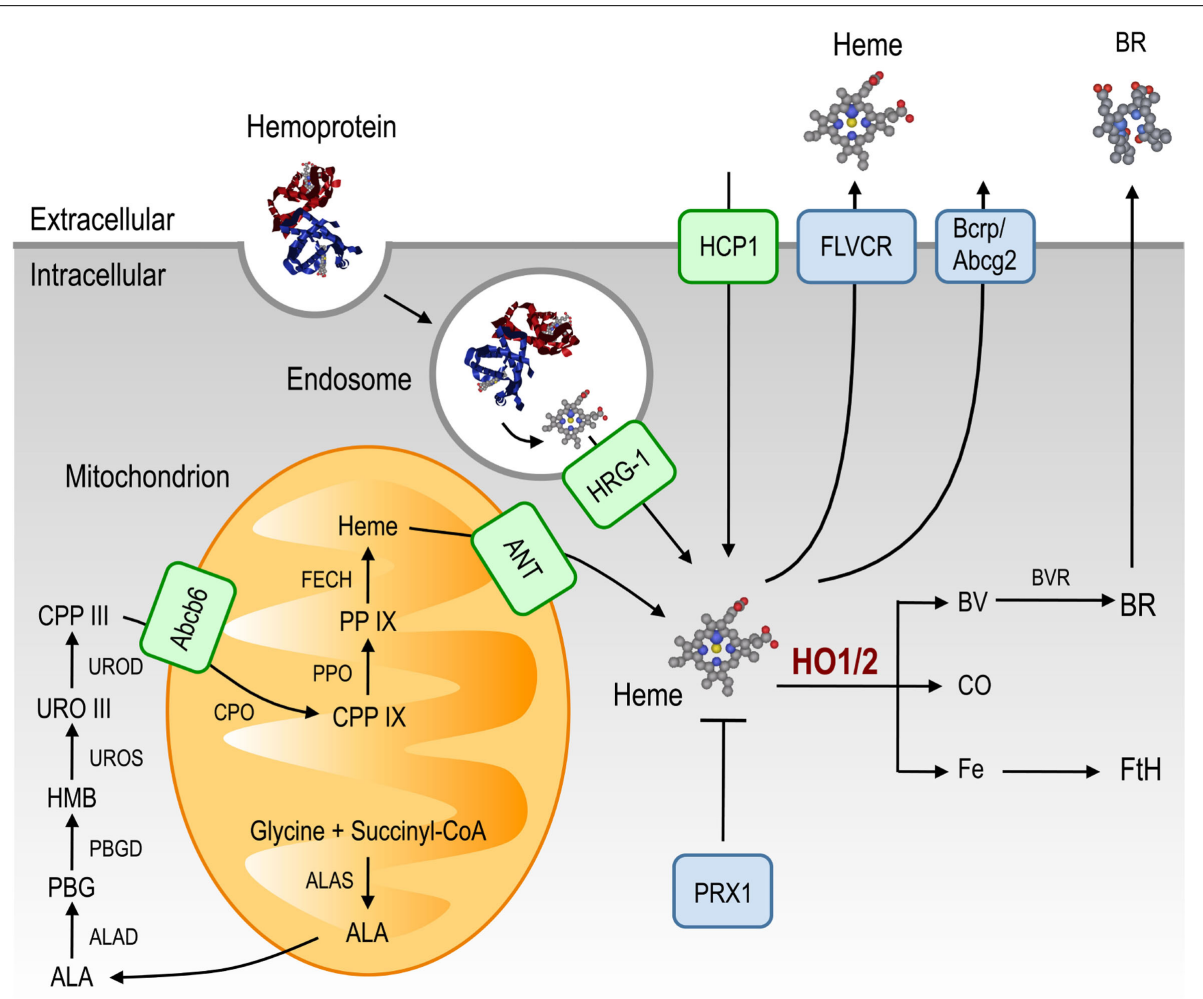

FIGURE 1 | Heme metabolism. Heme is synthesized from glycine and succinyl-CoA, through eight enzymatic steps that take place in the cytoplasm and the mitochondrion. Heme and heme precursors are transported between these compartments by ANT and Abcb6, respectively. In addition to the heme produced via this pathway, extracellular heme can be imported. Hemoproteins can be taken up and denatured in endosomes, liberating heme that can be transported to the cytoplasm via HRG-1, whereas cell-free heme is taken up by the cell membrane-associated HCP1. Cytoplasmic heme can be scavenged by PRX1, which neutralizes its pro-oxidant effects. Excess heme can be exported via FLVCR and Bcrp/Abcg2 or catabolized by HO-1/2 into equimolar amounts of BV, $\mathrm{CO}$ and free Fe. BV can be converted into BR by BVR while labile cellular Fe induces the expression of $\mathrm{FtH}$ that scavenges excess cellular Fe. Abbreviations: Abcb6, ATP-binding cassette b6; ALA, $\delta$-aminolevulinic acid; ALAD, ALA dehydratase; ALAS, ALA synthase; ANT, adenine-nucleotide translocator; Bcrp/Abcg2, breast cancer resistance protein/ATP-binding cassette g2; BR: bilirubin; BV, biliverdin; BVR, BV reductase; $\mathrm{CO}$, carbon monoxide; $\mathrm{CPP}$, coproporphyrinogen; CPO, CPP oxidase; Fe, iron; $\mathrm{FECH}$, ferrochelatase; FLVCR, feline leukemic virus receptor; Fth, ferritin; HCP1, heme carrier protein-1; HMB, hydroxymethylbilane; HO, heme oxygenase; HRG-1, heme responsive gene-1; PBG, porphobilinogen; PBGD, PBG deaminase; PP IX, protoporphyrin IX; PPO, protoporphyrinogen oxidase; PRX1, peroxiredoxin-1; URO, uroporphyrinogen; UROD, URO decarboxylase; UROS, URO III synthase. expression (Hamilton et al., 1991) or ALAS translocation from the cytoplasm into the mitochondrion (Lathrop and Timko, 1993).

\section{HEME TRANSPORT}

Being hydrophobic, heme was assumed to diffuse passively across cellular membranes. However, heme cellular trafficking appears to be controlled by a range of evolutionary conserved heme transporters (Figure 1; reviewed in Schultz et al., 2010; Khan and Quigley, 2011). Some of these heme transporters, e.g., mitochondrial ATP-binding cassette (ABC) family member, Abcb6, and the adenine-nucleotide translocator (ANT), control the translocation of heme as well as that of heme precursors between the cytoplasm and the mitochondria (Figure 1; Krishnamurthy et al., 2006; Azuma et al., 2008). Other heme transporters, including HRG-1 expressed in endosomes and lysosomes (Rajagopal et al., 2008) or the heme carrier protein (HCP1) expressed in the cytoplasmic membrane, control extracellular heme import (Figure 1; Shayeghi et al., 2005; Latunde-Dada et al., 2006; Figure 1). Heme can also be exported from cells via the ATP-binding cassette (Abcg2;
Krishnamurthy et al., 2004; Krishnamurthy and Schuetz, 2006) and the feline leukemic virus receptor (FLVCR; Figure 1; Quigley et al., 2000, 2004; Schultz et al., 2010).

\section{HEME CATABOLISM}

Heme degradation can be catalyzed by the enzymatic activity of heme oxygenases (HO; Tenhunen et al., 1968. There are two isoforms, i.e., HO-1 and HO-2, encoded by the HMOX1 and HMOX2 genes in humans, respectively (Figure 1; Maines et al., 1986; Trakshel et al., 1986). HO-2 is constitutively expressed by most cells (Trakshel et al., 1986) and is thought to carry out heme catabolism under homeostatic conditions. In contrast, excess intracellular heme induces the expression of the stress-responsive HO-1 isoform (see $\mathrm{HO}$-Catalyzed Heme Degradation), increasing the rate of heme catabolism and, as such, preventing its putative cytotoxic effects (Gozzelino et al., 2010). HO activity catalyzes the oxidative cleavage of the heme protoporphyrin IX ring, yielding biliverdin (BV), concomitant with the release of equimolar amounts of labile Fe and carbon monoxide (CO; Figure 1; Tenhunen et al., 1968). 
Biliverdin is converted into bilirubin (BR) by BV reductase (Kutty and Maines, 1981; Figure 1). The physiological roles of these end products of heme catabolism, are discussed in further detail under Section "Cellular Control of Free Heme."

\section{PATHOPHYSIOLOGICAL EFFECTS OF FREE HEME}

Under pathophysiological conditions, heme $b$ can be released from hemoproteins to which it binds non-covalently (Bunn and Jandl, 1968; Hebbel et al., 1988; Pamplona et al., 2007). This produces "free heme", that is, heme that is not bound to the heme pockets of hemoproteins. Free heme can act as a potent cytotoxic pro-oxidant (Balla et al., 1992, 1993) owing to the Fe atom contained within its protophorphyrin ring (Seixas et al., 2009; Gozzelino and Soares, 2011).

Immune-mediated inflammatory diseases can be associated with the accumulation of free heme in the circulation (Reiter et al., 2002; Pamplona et al., 2007; Seixas et al., 2009; Andrade et al., 2010a,b; Larsen et al., 2010). The observation that free heme can sensitize non-hematopoietic cells, e.g., hepatocytes, to undergo programmed cell death (PCD) in response to a variety of pro-inflammatory agonists (Seixas et al., 2009; Larsen et al., 2010; Gozzelino and Soares, 2011), suggests that free heme may participate functionally in the pathogenesis of immuno-mediated inflammatory diseases (Figure 2; Francis et al., 1997), in which the host component of inflammation would exacerbate the deleterious effects of free heme (Seixas et al., 2009; Larsen et al., 2010; Gozzelino and Soares, 2011). Taking this into account, the amount of circulating free heme, as a result of the overall heme metabolism, would dictate the outcome of these pathologic conditions. While free heme also appears to exert pro-inflammatory effects (Figueiredo et al., 2007; Porto et al., 2007; Fernandez et al., 2010) that might participate in the pathogenesis of immunemediated inflammatory diseases these will not be covered in detail hereby.

Presumably, the cytotoxic effect of free heme is mediated, to a large extent, via the unfettered production of free radicals leading to oxidative stress. This notion is supported by the observation that pharmacologic antioxidants can confer cytoprotection against free heme (Seixas et al., 2009; Larsen et al., 2010). Sustained free radicals production can prolong the activation of the c-Jun $\mathrm{N}$ terminal Kinase (JNK) signaling transduction pathway (Ventura et al., 2004; Kamata et al., 2005), via inhibition of phosphatases controlling JNK activation in response to tumor necrosis factor (TNF; Davis, 2000; Sanchez-Perez et al., 2000; Masuda et al., 2001; Tanoue et al., 2001; Kamata et al., 2005; Figure 2). The cytotoxic effect of free heme is owed to this sustained JNK activation, as suggested by the observation that heme-driven free radical production leads to sustained JNK phosphorylation/activation (Figure 2) and that inhibition of JNK activation affords cytoprotection against free heme (Raffaella Gozzelino et al., unpublished results). The cytotoxic effect of free heme is also associated with cleavage of caspase-3, suggesting that heme sensitizes non-hematopoietic cells, e.g., hepatocytes, to undergo PCD by apoptosis. This notion is supported by the demonstration that pharmacologic caspase inhibition, including specific inhibition of caspase-3, confers cytoprotection against free heme (Figure 2; Seixas et al., 2009). More recently, free heme has also been shown to trigger necroptosis

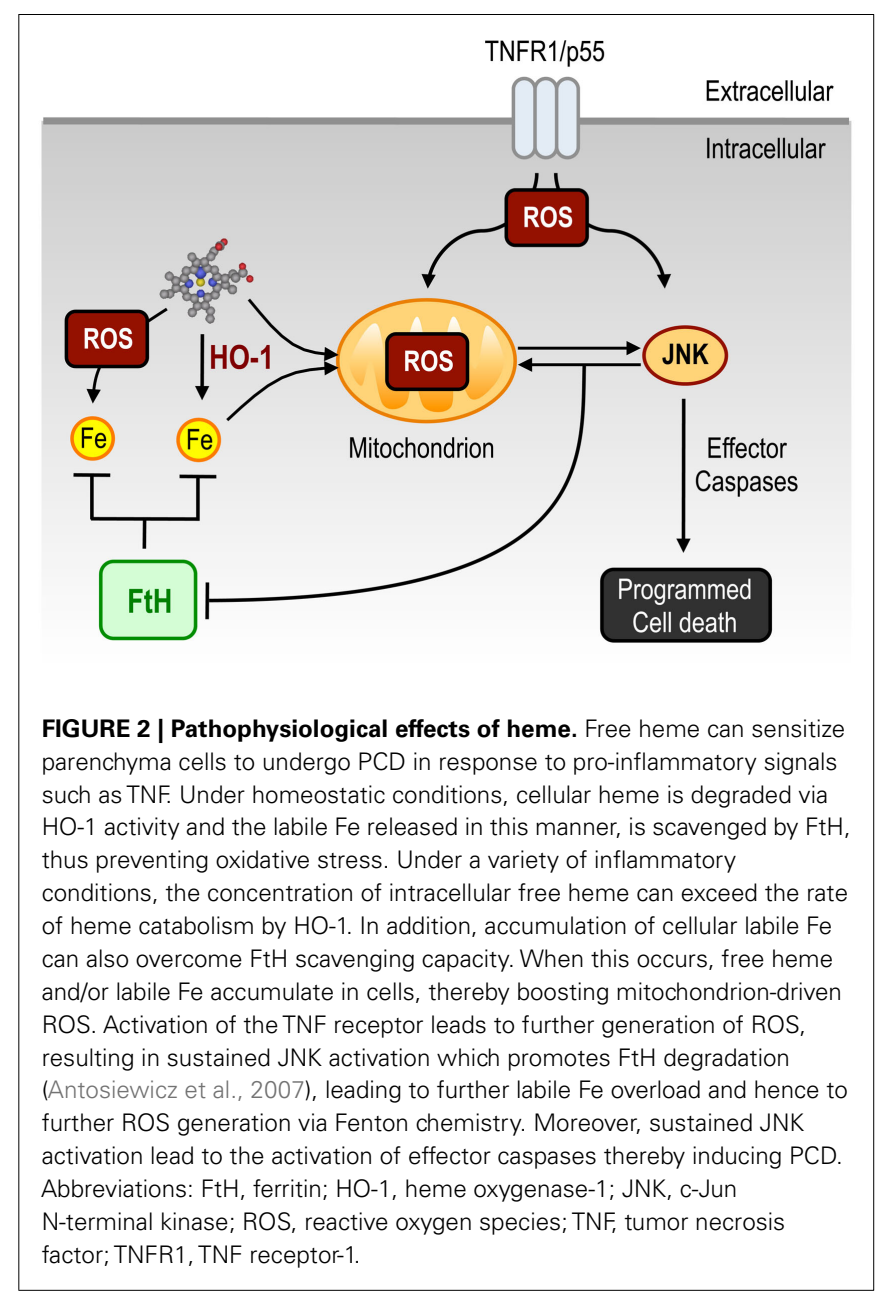

in hematopoietic cells, as demonstrated for macrophages (Fortes et al., 2012).

\section{PHYSIOLOGIC MECHANISMS OF PROTECTION AGAINST FREE HEME}

Under pathophysiologic conditions associated with intravascular hemolysis, significant amounts of $\mathrm{Hb}$ can be released from red blood cells (RBCs). The resulting circulating cell-free $\mathrm{Hb}$ undergoes oxidation, releasing its prosthetic heme groups (Bunn and Jandl, 1968; Hebbel et al., 1988; Pamplona et al., 2007; Ferreira et al., 2008). Similarly, oxidation of other hemoproteins, e.g., myoglobin, may also contribute to the unwarranted accumulation of cytotoxic free heme, such as associated with rhabdomyolysis (Nath et al., 1992).

Protective mechanisms are in place, on systemic as well as cellular levels, to deal with this challenge, as described in this section.

\section{SYSTEMIC CONTROL OF FREE HEME}

Cell-free $\mathrm{Hb}$ can be scavenged by haptoglobin ( $\mathrm{Hp}$ ), an acute phase protein synthesized in the liver and present at relatively high concentrations $(0.3-3 \mathrm{mg} / \mathrm{mL}$ ) in plasma (Levy et al., 2010). Binding of $\mathrm{Hb}$ to $\mathrm{Hp}$ prevents $\mathrm{Hb}$ oxidation (Melamed-Frank et al., 2001) 
and thereby the release of its heme moiety (Figure 3). $\mathrm{Hb}: \mathrm{Hp}$ complexes binds to CD163 (Kristiansen et al., 2001) expressed in macrophages and hepatocytes (Philippidis et al., 2004; Quaye, 2008), leading to endocytosis and degradation of the Hb:Hp complex (Figure 3). Polymorphisms in the human HPT gene can act as independent risk factors for several immune-mediated inflammatory diseases (Quaye, 2008), suggesting that Hb scavenging by $\mathrm{Hp}$ modulates the pathogenesis of these diseases.

Under pathophysiological conditions associated with more or less extensive intravascular hemolysis, such as malaria or different forms of hemolytic anemia (see Heme and the Pathogenesis of Infectious Diseases and Heme and the Pathogenesis of NonInfectious Immune-Mediated Inflammatory Conditions), extracellular $\mathrm{Hb}$ can lead to the depletion of circulating Hp (MullerEberhard et al., 1968; Rother et al., 2005). When Hb accumulates in the circulation it becomes oxidized, releasing its heme groups (Bunn and Jandl, 1968; Hebbel et al., 1988; Pamplona et al., 2007; Ferreira et al., 2008). A number of circulating proteins can scavenge free heme in plasma (Bunn and Jandl, 1966; Figure 3), including hemopexin (Paoli et al., 1999; Tolosano et al., 2010), albumin (Fasano et al., 2007), $\alpha 1$-microglobulin (Allhorn et al., 2002) and high- and low-density lipoproteins (Miller and Shaklai, 1999).
Hemopexin $(\mathrm{Hx})$ is an acute phase protein present at high concentrations in plasma $(0.6-1.2 \mathrm{mg} / \mathrm{mL})$, with the highest binding affinity for free heme $\left(K_{\mathrm{d}}<10^{-12}\right.$ in humans) of any described protein (Paoli et al., 1999; Tolosano et al., 2010). Heme:Hx complexes, which inhibits Fe-heme reactivity (Eskew et al., 1999), are recognized by the macrophage CD91 receptor (Hvidberg et al., 2005), allowing for intracellular heme catabolism (Figure 3; Alam and Smith, 1989). Hx is not degraded by macrophages, to any significant extent, being secreted back into the circulation (Figure 3; Hvidberg et al., 2005). As a consequence, $\mathrm{Hx}$ is less prone to complete depletion from the circulation, as compared to $\mathrm{Hp}$.

Mice deficient in $\mathrm{Hx}$ and/or $\mathrm{Hp}\left(\mathrm{Hpx}^{-/-} \mathrm{Hpt}^{-/-}\right)$develop severe renal damage when subjected to hemolysis, suggesting that $\mathrm{Hx}$ is part of a systemic protective mechanism against the deleterious effects of circulating free heme (Tolosano et al., 1999). The reason for which the kidney appears to be the first target of heme cytotoxicity in vivo is not clear, but is in keeping with the observation that induction of heme catabolism prevents kidney injury driven by rhabdomyolysis, where the hemoprotein, myoglobin, is released into circulation (Nath et al., 1992).

Albumin can bind heme with an affinity $10^{4}$ times lower than Hx $\left(K_{\mathrm{d}}=10^{-8}\right.$; Little and Neilands, 1960). However, the high

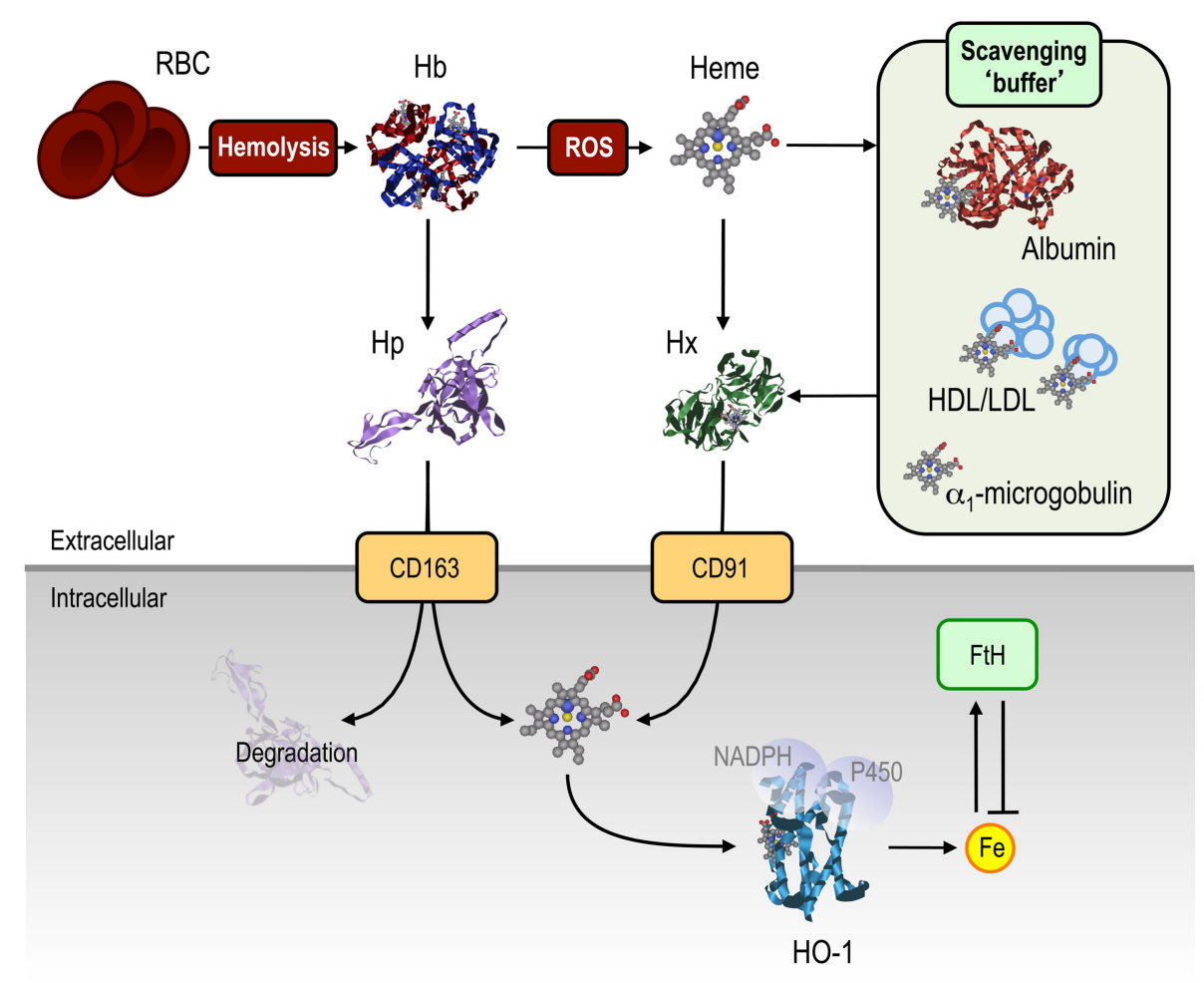

FIGURE 3 | Mechanisms of protection against free heme. A range of extracellular mechanisms confer protection against cell-free $\mathrm{Hb}$ and heme. Under hemolytic conditions, $\mathrm{Hb}$ is released from $\mathrm{RBC}$ into the circulation where it is scavenged by $\mathrm{Hp}$, thereby preventing $\mathrm{Hb}$ oxidation, and allowing for the uptake of $\mathrm{Hb}: \mathrm{Hp}$ complexes via the CD163 receptor. Once the scavenging capacity of $\mathrm{Hp}$ is exhausted, $\mathrm{Hb}$ becomes oxidized, releasing its heme prosthetic groups. These can be scavenged by albumin, HDL and LDL, a1-microglobulin, acting as "scavenging buffer," and ultimately by $\mathrm{Hx}$, which has the highest affinity for free heme. Hx:heme complexes are taken up via the CD91 receptor, delivering heme for catabolism by HO-1. Intracellular heme, whether originating from the extra- or intracellular compartment, is degraded via HO-1. The labile Fe released from heme catabolism is subsequently scavenged by $\mathrm{FtH}$, thus conferring cytoprotection against heme-Fe. Abbreviations: Fe, iron; $\mathrm{FtH}$, ferritin; $\mathrm{Hp}$, haptoglobin; $\mathrm{Hb}$, hemoglobin; HDL/LDL, high/low-density lipoprotein; Hx, hemopexin; ROS, reactive oxygen species. 
concentration of albumin in plasma $(\sim 43 \mathrm{mg} / \mathrm{mL})$ might compensate to some extent for its low affinity (Figure 3). Heme binding to albumin can neutralize the pro-oxidant effect of free heme, which may explain the protective effect of albumin infusion to individuals developing severe forms of sepsis (Delaney et al., 2011) or malaria (Maitland et al., 2005; Akech et al., 2006), the pathogenesis of which are driven to a significant extent by free heme (Pamplona et al., 2007; Ferreira et al., 2008; Seixas et al., 2009; Larsen et al., 2010; Raffaella Gozzelino et al., unpublished results).

$\alpha 1$-Microglobulin is a member of the lipocalin protein superfamily, that binds small lipophilic ligands (Flower et al., 2000). Cell-free $\mathrm{Hb}$ can cleave $\alpha 1$-microglobulin, into a truncated protein that binds $\left(K_{\mathrm{d}}=10^{-6}\right)$ and converts free heme into a yellowbrown proteinaceous chromophore, subsequently cleared by renal filtration (Allhorn et al., 2002). Binding of $\alpha 1$-microglobulin to heme neutralizes its pro-oxidant effect, suggesting that $\alpha 1$ microglobulin acts as a heme scavenger in circulation (Figure 3; Allhorn et al., 2002). Whether under pathophysiologic conditions $\alpha 1$-microglobulin plays a protective role against heme is unknown.

High- and low-density lipoproteins (HDL and LDL, respectively) can bind heme $\left(K_{\mathrm{d}} \sim 10^{-11}-10^{-12}\right)$ with faster kinetics to those of Hx or albumin (Miller and Shaklai, 1999), thereby acting as the initial heme scavengers in circulation (Balla et al., 1991; Jeney et al., 2002). Once bound to HDL and LDL, heme can be transferred to Hx (Figure 3; Morgan et al., 1976; Hvidberg et al., 2005). In this manner, HDL and LDL may function as an initial "buffer" for circulating heme. Binding of heme to HDL or LDL oxidizes HDL and LDL that are then cleared via the CD36 and CD68 scavenger receptors expressed on macrophages (Camejo et al., 1998; Miller and Shaklai, 1999). Of note, however, oxidized HDL and LDL are cytotoxic (Jeney et al., 2002; Stocker and Perrella, 2006), suggesting that heme-mediated lipid peroxidation might be a key mechanism via which heme exerts its deleterious effects (Jeney et al., 2002; Stocker and Perrella, 2006). This also indicates that the beneficial role of HDL and LDL in circulation would be dependent on their rapid clearance that might otherwise be detrimental. Considering its high affinity for heme, $\mathrm{Hx}$ acts most probably as an ultimate heme scavenger in plasma, targeting heme bound to other carrier proteins or not, and allowing for heme delivery for intracellular degradation by the $\mathrm{HO}$ system (see $\mathrm{HO}$-Catalyzed Heme Degradation).

\section{CELLULAR CONTROL OF FREE HEME \\ Heme incorporation into hemoproteins}

The rate of de novo heme synthesis must correspond accurately to its rate of incorporation into newly synthesized apohemoproteins. This is regulated at different levels via the control of heme (see Heme Metabolism) as well as apo-hemoprotein synthesis. Free heme can induce the transcription and hence the expression of several apo-hemoproteins, as demonstrated for $\mathrm{Hb}$, myoglobin and neuroglobin in erythroid, muscle and neuronal cells, respectively (Bruns and London, 1965; Tahara et al., 1978; Graber and Woodworth, 1986; Zhu et al., 2002a,b). This evolutionary conserved strategy prevents intracellular heme accumulation, presumably limiting heme cytotoxicity.

\section{HO-catalyzed heme degradation}

Whereas HO-2 is responsible for homeostatic heme catabolism (see Heme Catabolism), HO-1 can be induced by different forms of stress (Choi and Alam, 1996). Oxidative stress can lead to heme release from hemoproteins (reviewed in Gozzelino et al., 2010), requiring a cellular adaptive response maintaining intracellular free heme below a cytotoxic threshold level. This is accomplished, to a large extent, via the induction of $H M O X 1$ transcription and HO-1 expression (Alam et al., 1994, 1995; Choi and Alam, 1996; Alam and Cook, 2007). In line with this notion, mouse cells deficient in HO- 1 expression $\left(\mathrm{Hmox}^{-/-}\right)$, and thus unable to increase heme catabolism in response to different forms of stress, display exacerbated cytotoxicity in response to oxidative stress (Poss and Tonegawa, 1997a,b; Yet et al., 2003; Bishop et al., 2004). Whether this is, as speculated hereby, due to the accumulation of free heme or whether HO-1 acts in a cytoprotective manner independently of its ability to neutralize the cytotoxic effect of free heme, remains unclear.

Induction of HO-1 expression in response to infection can be essential to sustain host survival, as demonstrated for systemic polymicrobial (Larsen et al., 2010) as well as for Plasmodium infection (Pamplona et al., 2007; Seixas et al., 2009), the causative agent of malaria. Accumulation of heme in the circulation is cytotoxic, thus leading to tissue damage and, as such, exacerbating the pathologic outcome of these diseases (Pamplona et al., 2007; Seixas et al., 2009; Larsen et al., 2010). HO-1 neutralizes this cytotoxic effect and hence provides tissue damage control and host protection against infections (Pamplona et al., 2007; Larsen et al., 2010; reviewed in Gozzelino et al., 2010). This host defense strategy acts irrespectively of pathogen load, a phenomenon referred to as host tolerance to infection (Medzhitov et al., 2012).

The cytoprotective action of HO-1 (Vile et al., 1994; Soares et al., 1998) resides not only in the degradation of cytotoxic heme, but also in the production of the different end products of heme catabolism, namely CO, BV, and labile Fe (Figure 3). $\mathrm{CO}$ has a variety of biological effects that mitigate the pathogenesis and/or progression of immune-mediated inflammatory diseases (Otterbein et al., 1999b; Fujita et al., 2001; Sato et al., 2001). These include its ability to bind the Fe atom in the prosthetic heme groups of hemoproteins, thereby modulating their function (Kim et al., 2006; Piantadosi, 2008; Mustafa et al., 2009). This mechanism of action probably underlies the cytoprotective (Brouard et al., 2000; Silva et al., 2006) and "anti-inflammatory" effects of CO (Otterbein et al., 2000) as well as the ability of this gasotransmitter to inhibit platelet activation and aggregation (Brune and Ullrich, 1987). In addition, binding of CO to the Feheme prevents the oxidation of hemoproteins, thereby slowing down heme release. When exerted over cell-free $\mathrm{Hb}$ (Hebbel et al., 1988; Pamplona et al., 2007), CO prevents heme release from Hb, suppressing the pathogenesis of severe forms of malaria (Pamplona et al., 2007; Ferreira et al., 2008). Presumably this mechanism should contribute to prevent the pathogenesis and/or progression of other immune-mediated inflammatory diseases associated with heme release from hemoproteins (reviewed in Ferreira et al., 2008; Gozzelino et al., 2010).

Biliverdin is converted into lipid phase antioxidant BR (Stocker et al., 1987) by BV reductase (BVR; Figure 3; Singleton and Laster, 
1965; Kutty and Maines, 1981). The BV/BR system affords cytoprotection against reactive oxygen species (ROS; Dore et al., 1999; Baranano et al., 2002). Both free heme and BR are lipophilic, suggesting that the antioxidant action of BR may limit lipid oxidation by free heme. Presumably, the cytoprotective effect of BV/BR contributes to their overall protective effect against a range of immune-mediated inflammatory diseases (Yamashita et al., 2004; Ollinger et al., 2005, 2007; Sarady-Andrews et al., 2005; Overhaus et al., 2006; Wang et al., 2006).

The Fe released from the protoporphyrin IX ring of heme (Figure 3) can catalyze the generation of ROS via Fenton chemistry (Fenton, 1894). Cells can neutralize this cytotoxic effect by secreting Fe via Fe efflux pumps (Ferris et al., 1999; Baranano et al., 2000) or by storing Fe inside ferritin (Figure 3; Eisenstein et al., 1991; Harrison and Arosio, 1996; Baker et al., 2003), a multimeric protein complex composed of a heavy/heart chain $(\mathrm{FtH})$ and a light/liver chain (FtL) that store up to 4500 Fe molecules (Harrison and Arosio, 1996). The FtH subunit possesses ferroxidase activity that allows it to catalyze the conversion of $\mathrm{Fe}^{2+}$ into $\mathrm{Fe}^{3+}$, required for Fe storage. FtH is cytoprotective against TNF (Ferris et al., 1999; Berberat et al., 2003; Cozzi et al., 2003; Xie et al., 2005) as well as heme-driven cytotoxicity (Balla et al., 1992). This salutary effect relies on the ability of FtH to neutralize the pro-oxidant activity of labile Fe, thereby preventing sustained JNK activation (Pham et al., 2004; Raffaella Gozzelino et al., unpublished results). Presumably, the cytoprotective effect of $\mathrm{FtH}$ prevents the pathogenesis of immune-mediated inflammatory diseases, such as demonstrated originally for ischemia-reperfusion injury (IRI; Berberat et al., 2003) and more recently for malaria (Raffaella Gozzelino et al., unpublished results).

\section{Heme transport and secretion}

Proteins involved in heme transport or intracellular heme scavenging (see Heme Transport) should regulate the pro-oxidant effects of heme (Figure 1; reviewed in Schultz et al., 2010; Khan and Quigley, 2011). Expression of the intracellular heme-binding thioredoxin-dependent peroxidase (PRX-1) is induced transcriptionally by heme as well as by oxidative stress (Immenschuh et al., 1995, 2005). PRX1 negates the pro-oxidant effect of free heme, preventing its deleterious effects (Immenschuh et al., 1995, 2005). Expression of the ubiquitous heme exporter, FLVCR, can also provide protection against cytotoxic free heme (Quigley et al., 2004; Keel et al., 2008; reviewed in Khan and Quigley, 2011). The Abcg2 transporter can export intracellular PPIX, delivering heme to extracellular albumin (Szatmari et al., 2006) and as such may be considered, together with FLVCR, as a therapeutic target to promote cell survival against heme-mediated cytotoxicity.

\section{HEME AND THE PATHOGENESIS OF INFECTIOUS DISEASES}

Failure to control the deleterious effects of free heme can contribute to the pathogenesis of a number of pathologies, associated with heme release from $\mathrm{Hb}$ or other hemoproteins.

\section{SEVERE SEPSIS}

Severe sepsis develops from an exacerbated inflammatory response to microbial infection, leading to systemic refractory hypotension, disseminated intravascular coagulation, multiple end-stage organ failure and ultimately to death (reviewed in Cohen, 2002; Hotchkiss and Karl, 2003). The mechanisms underlying the pathogenesis of severe sepsis remains poorly understood (reviewed in Cohen, 2002; Riedemann et al., 2003; Ulloa and Tracey, 2005). We have recently identified heme as a central component in the pathogenesis of this acute inflammatory disease (Larsen et al., 2010).

Severe sepsis driven by polymicrobial infection can be induced experimentally in mice by cecal ligation and puncture (CLP; Rittirsch et al., 2009). Disease progression is associated with RBC deformation (poikilocytosis), accumulation of cell-free $\mathrm{Hb}$ and free heme as well as with decreased concentration of $\mathrm{Hp}$ and $\mathrm{Hx}$ in plasma (Larsen et al., 2010). Poikilocytosis (Piagnerelli et al., 2003; Bain, 2005) and decreased concentration of Hx in plasma (Larsen et al., 2010) are also observed in human sepsis. This indicates that in the absence of overt hemolysis, significant amounts of Hb can be released from $\mathrm{RBC}$ resulting in heme accumulation in the circulation. A number of factors can contribute to this (Kempe et al., 2007; Lang et al., 2008), including deregulated plasma osmolarity, acidosis, bacterial hemolysins (particularly Clostridium perfringens; Gutierrez et al., 1995), or free heme itself (Sil et al., 2004). The pathophysiologic relevance of these findings is supported by the observations that lethality driven by severe sepsis is associated with decreased levels of $\mathrm{Hx}$ in plasma and that administration of purified $\mathrm{Hx}$, after the onset of lethal sepsis in mice, improves host survival (Larsen et al., 2010). This suggests that targeting free heme, such as using $\mathrm{Hx}$, might be used therapeutically to treat severe forms of sepsis.

As discussed above (see Pathophysiological Effects of Free Heme) free heme sensitizes cells in parenchymal tissues to undergo PCD in response to a variety of pro-oxidant and/or inflammatory compounds (Seixas et al., 2009; Gozzelino et al., 2010; Larsen et al., 2010). This cytotoxic effect might contribute to the development of organ failure associated with severe sepsis. This may also explain why therapeutic targeting of single pro-inflammatory molecules, e.g., the cytokine TNF (Cohen and Carlet, 1996) or IL-1 (Opal et al., 1997) have failed as a treatment for severe sepsis, while targeting free heme may be a valuable therapeutic option, since heme acts as a cytoxic catalyst for these as well as other pro-inflammatory molecules.

It should be noted that the accumulation of free heme in the circulation of septic patients and mice does not have to derive exclusively from the oxidation of cell-free $\mathrm{Hb}$. It is possible that heme $b$ is released from the oxidation of other hemoproteins to which it binds non-covalently, such as myoglobin released during rhabdomyolysis associated with septic shock (Kumar et al., 2009).

\section{MALARIA}

Together with sepsis, malaria remains a major cause of morbidity and mortality worldwide, in particular in subtropical countries where it affects millions of individuals every year (Murray et al., 2012). Malaria develops in response to Plasmodium infection, at a specific stage of the life cycle of this protozoan parasite associated with RBC lysis (Miller et al., 2002). This so-called "blood stage" of infection is associated with hemolysis and hence with oxidation of cell-free $\mathrm{Hb}$ and production of free heme (Ferreira et al., 2008).

All the clinical manifestations of malaria, from fever to respiratory distress, circulatory collapse, abnormal bleeding, jaundice, 
hemoglobinuria, severe anemia, convulsions, prostration, and/or impaired consciousness are associated with the blood stage of infection (Idro et al., 2005) and as such with the accumulation of cell-free $\mathrm{Hb}$ and heme in plasma. When an individual presents with one or more of these symptoms, with no cause of disease other than Plasmodium infection, he is defined as developing a severe form of malaria (Marsh et al., 1995; Maitland and Marsh, 2004).

That non-Hb bound heme contributes to the pathogenesis of severe forms of malaria is suggested by the following observations in mice. Severity of Plasmodium infection correlates with the accumulation of cell-free $\mathrm{Hb}$ and non- $\mathrm{Hb}$ bound free heme in plasma (Pamplona et al., 2007; Ferreira et al., 2008; Andrade et al., 2010a). The same is true in humans (Andrade et al., 2010a). Free heme is sufficient to elicit the onset of severe forms of malaria in Plasmodium infected mice (Pamplona et al., 2007; Ferreira et al., 2008, 2011; Seixas et al., 2009). Heme catabolism by HO-1 suppresses the pathogenesis of severe forms of malaria in mice (Pamplona et al., 2007; Seixas et al., 2009; Ferreira et al., 2011) and is associated with the pathologic outcome of malaria in humans as well (Andrade et al., 2010a; Sambo et al., 2010; Walther et al., 2012).

The pathologic effect of free heme is most probably driven by the Fe atom released from the protoporphyrin ring of heme, either through catabolism by HO-1 (Tenhunen et al., 1968) or via nonenzymatic oxidative degradation (Schaefer et al., 1985; Nagababu and Rifkind, 2000, 2004). The deleterious effects of labile Fe can be countered by FtH (Balla et al., 1992), probably explaining why $\mathrm{FtH}$ prevents the onset of severe forms of malaria in mice (Raffaella Gozzelino et al., unpublished results).

\section{HEME AND THE PATHOGENESIS OF NON-INFECTIOUS IMMUNE-MEDIATED INFLAMMATORY CONDITIONS HEMOLYTIC DISORDERS}

A number of hereditary diseases associated with defects in RBC function can lead to premature RBC senescence, associated with increased hematophagocytosis as well as with the release of $\mathrm{Hb}$ and heme into circulation. Heme toxicity may contribute to the clinical complications of these diseases, as illustrated in this section for sickle cell anemia and G6PD deficiency.

\section{Sickle cell disease}

Sickle cell disease is a molecular disease (Pauling et al., 1949) caused by a single point mutation in the $\beta$ chain of $\mathrm{Hb}$ $(\beta 6 \mathrm{Glu}>\mathrm{Val})$, leading to the synthesis of a modified $\mathrm{Hb}$ variant generally referred to as HbS (Williams et al., 2005a; Jallow et al., 2009). Other sickle mutations include HbC ( $\beta 6$ Glu > Lys; Modiano et al., 2001) and HbE ( $\beta 6$ Glu > Lys; Hutagalung et al., 1999).

When present in the homozygous form, the $\mathrm{Hb} \beta 6 \mathrm{Glu}>\mathrm{Val}$ sickle mutation becomes pathologic, leading under low oxygen pressure to $\mathrm{Hb}$ polymerization, $\mathrm{RBC}$ deformation (sickle shape), shortened RBC half-live and eventually to hemolysis. This is associated with $\mathrm{Hb}$ and heme release into circulation (Hebbel et al., 1988; Reiter et al., 2002). The disease manifests by a range of clinical outcomes that include episodes of vascular occlusion/dysfunction eventually leading to the development of stroke and/or renal failure. Sickle cell anemia is also associated with tissue Fe overload, presumably driven by chronic accumulation of free heme in the circulation (Hebbel et al., 1988; Reiter et al., 2002).

Cell-free $\mathrm{Hb}$ is thought to contribute to the pathogenesis of sickle cell anemia, essentially by scavenging NO (Reiter et al., 2002), thereby promoting vasoconstriction, platelet aggregation and expression of adhesion molecules associated with endothelial cell activation (Belcher et al., 2003). Interaction of NO with cellfree $\mathrm{Hb}$ also catalyzes the production of free radicals, promoting $\mathrm{Hb}$ oxidation and heme release. Further oxidation of cell-free $\mathrm{Hb}$ can lead to the formation of ferrylHb aggregates acting as a proinflammatory agonist in the vascular endothelium (Silva et al., 2009).

Expression of HO-1 or administration of exogenous CO counters the pathological outcome of sickle cell disease (Belcher et al., 2006). Presumably this protective effect is mediated via inhibition of endothelial cell activation (Soares et al., 2004; Seldon et al., 2007). In addition, this salutary effect may also be mediated via inhibition of $\mathrm{Hb}$ oxidation, preventing heme release from cell-free $\mathrm{Hb}$. If this proves to be the case, then targeting cell-free $\mathrm{Hb}$ or free heme in plasma using $\mathrm{Hp}$ or $\mathrm{Hx}$ should ameliorate the pathological outcome of sickle cell disease as well.

When present in the heterozygous form, the $\mathrm{Hb} \beta 6 \mathrm{Glu}>\mathrm{Val}$ sickle mutation is not pathogenic, conferring instead a net survival advantage to human population living in endemic areas of malaria (Williams et al., 2005b). This protective effect acts via a mechanism involving the accumulation of low (non-cytotoxic) levels of free heme in plasma that induce the expression of $\mathrm{HO}$ 1 via activation of the transcription factor NF-E2-related factor 2 (Nrf2; Ferreira et al., 2011). The CO produced via heme catabolism by $\mathrm{HO}-1$ binds to cell-free $\mathrm{Hb}$ and prevents the accumulation of high levels (cytotoxic) of circulating free heme following Plasmodium infection, thus suppressing the pathogenesis of severe forms of malaria (Ferreira et al., 2011). This protective effect does not interfere with parasite load revealing that sickle $\mathrm{Hb}$ confers tolerance against Plasmodium infection (Ferreira et al., 2011). That is, it promotes host survival irrespectively of its pathogen load (Medzhitov et al., 2012).

\section{Glucose-6-P dehydrogenase deficiency}

RBC lack mitochondria and as such cannot generate NAPDH via oxidative phosphorylation. Glucose-6-phosphate dehydrogenase (G6PD) catalyzes the first step of the pentose phosphate pathway of glucose metabolism, and is a critical mechanism for the generation of reducing power via RBC NADPH. More than 140 G6PD mutations have been reported, leading to RBC oxidative stress and eventually to varying degrees of hemolysis (reviewed in Cappellini and Fiorelli, 2008). The clinical outcomes associated with G6PD deficiency are revealed clinically by fatigue, jaundice (i.e., hepatic damage), increased circulating unconjugated BR and lactate dehydrogenase as well as reticulocytosis (Cappellini and Fiorelli, 2008). Presumably, some of these clinical outcomes can be explained by the release of $\mathrm{Hb}$ and heme into circulation, associated to chronic or acute episodes of hemolysis.

G6PD deficiency is one of the most common enzyme mutation in human populations (Mason, 1996) and is particularly prevalent in geographical areas where malaria is endemic. This suggests that mutations leading to the functional silencing of the human G6PD 
gene were naturally selected through evolution on the basis of the survival advantage they provide against malaria, a major driving force in human evolution (Cappellini and Fiorelli, 2008). The molecular mechanism via which G6PD mutations confer protection against Plasmodium infection are not clear but, as discussed in the previous section, this is likely to be related to the mechanism involved in the protection conferred by sickle $\mathrm{Hb}$ against malaria.

\section{PATHOLOGICAL COMPLICATIONS OF PREGNANCY}

The early stages of pregnancy in mammals are associated with the induction of high levels of $\mathrm{HO}-1$ expression by placental trophoblasts, as demonstrated in mice, rats, and humans (Ihara et al., 1998; Barber et al., 2001; Sollwedel et al., 2005; Zenclussen et al., 2011). This suggested that expression of HO-1 might be required to support early stages of pregnancy, a notion in keeping with the observation that Hmoxl deletion causes pre-natal lethality in mice (Poss and Tonegawa, 1997b; Yet et al., 1999; Tzima et al., 2009). Several studies have demonstrated that reduced HO1 expression and/or activity can promote miscarriages in rodents as well as in humans (Zenclussen et al., 2003, 2005), which is also the case for pre-eclampsia, probably the most severe pathological complication associated to human pregnancy (Ahmed et al., 2000).

A more detailed analysis of the mechanisms involved in prenatal lethality associated with Hmoxl deletion in mice revealed that HO-1 is required to sustain placental formation and function and hence fetal development and success of the early stages of pregnancy (Zenclussen et al., 2011). Presumably, the salutary effect of $\mathrm{HO}-1$ relies on its ability to prevent the accumulation of free heme, generated in the placenta from the oxidation of cell-free $\mathrm{Hb}$. This notion is supported by the observation that impairment of intrauterine fetal survival, driven by Hmoxl deletion, is associated with the accumulation of free heme in plasma, while heme administration to wild type $\left(H \operatorname{mox} \mathrm{I}^{+/+}\right)$mice is sufficient per se to impair fetal survival (Zenclussen et al., 2011). CO can be used therapeutically to prevent miscarriages in mice, inhibiting heme release from cell-free $\mathrm{Hb}$ and preventing the accumulation of circulating free heme (Zenclussen et al., 2011). This is, to the best of our knowledge, the first demonstration that heme can participate in the pathogenesis of an immune-mediated inflammatory condition that is not driven by infection.

\section{ISCHEMIA AND REPERFUSION INJURY}

Ischemia and reperfusion injury act as a major cause of pathology leading to myocardial infarction, stroke or damage associated with organ transplantation, among others. Ischemia refers to a more or less pronounced restriction of blood supply to a given organ, associated with lower than physiological supply of several essential molecules, including $\mathrm{O}_{2}$. In the event that blood flow is re-established, i.e., reperfusion, the ischemic tissue is confronted with an abrupt delivery of $\mathrm{O}_{2}$ that cannot be readily used by the mitochondrial electron transport chain. The excess $\mathrm{O}_{2}$ becomes available to oxidative enzymes, e.g., NADPH oxidase, catalyzing the generation of ROS, i.e., superoxide $\left(\mathrm{O}_{2} \bullet\right)$, hydrogen peroxide $\left(\mathrm{H}_{2} \mathrm{O}_{2}\right)$ and hydroxyl radical $(\mathrm{OH} \bullet)$. Accumulation of ROS above a certain threshold level causes oxidative stress, promoting PCD and tissue damage (Zhang et al., 2007a).
Expression of HO-1 exerts strong protective effects against IRI (reviewed in Soares and Bach, 2007), via a mechanism that is not clear but is likely to involve the catabolism of deleterious free heme, which is in keeping with the notion that hemolysis might act as an inherent component of the pathogenesis of IRI. Presumably, the cytotoxic effect of free heme contributes to promote tissue damage associated with IRI, explaining the salutary effects of HO-1 (Shen et al., 2005), CO (Fujita et al., 2001; Akamatsu et al., 2004) or FtH (Berberat et al., 2003) against this pathologic process.

\section{TRANSPLANTATION}

Mouse grafts can survive indefinitely when transplanted into immunosuppressed rats (Miyatake et al., 1998). Long-term survival relies on a cytoprotective response elicited in the transplanted organ, a phenomenon termed by Fritz H. Bach as "accommodation" (Soares et al., 1999). HO-1 expression in the transplanted organ is required to promote accommodation (Soares et al., 1998, 1999), a salutary effect mediated at least partially by CO (Sato et al., 2001; reviewed in Soares and Bach, 2007). While there are probably several mechanisms that can contribute to explain the salutary effects of HO-1 and $\mathrm{CO}$ in the context of organ transplantation, these are likely mediated by the capacity of HO-1 to prevent the deleterious effect of free heme (see HO-Catalyzed Heme Degradation above). This remains however to be established experimentally.

\section{TARGETING FREE HEME THERAPEUTICALLY TO TREAT IMMUNE-MEDIATED INFLAMMATORY DISEASES SYSTEMIC HEME TARGETING \\ Targeting heme proteins}

While CO appears to be a major component of the protective action exerted by HO enzymatic activity (Otterbein et al., 1999b; Brouard et al., 2000, 2002; Fujita et al., 2001; Sato et al., 2001; Akamatsu et al., 2004; Soares et al., 2004), the mechanism underlying the salutary effects of this gasotransmitter remain unclear. CO can bind $\mathrm{Fe}^{2+}$ within the prosthetic heme groups of hemoproteins and hence modulate their biologic function (see HO-Catalyzed Heme Degradation). Presumably, this underlies the capacity of CO to act in a cytoprotective manner (Brouard et al., 2000, 2002; Silva et al., 2006) as well as to modulate macrophage activation (Otterbein et al., 2000) and to control cell proliferation (Otterbein et al., 2003).

There is another major biological output associated with $\mathrm{CO}$ binding to the Fe atom in the prosthetic heme groups of hemoproteins that contributes to the salutary effects of this gasotransmitter. Namely, CO can inhibit Fe-heme oxidation, preventing as well hemoprotein oxidation. This inhibits heme release from hemoproteins, as demonstrated for $\mathrm{Hb}$ (Pamplona et al., 2007; Figure 4), which is sufficient per se to explain how this gasotransmitter prevents the pathological outcome of malaria (Pamplona et al., 2007; Ferreira et al., 2008; Rosenthal, 2011). This suggests that CO may be used pharmacologically as a supportive therapy for the treatment of life-threatening complications of malaria.

It is likely that in a similar manner to $\mathrm{Hb}, \mathrm{CO}$ may also prevent heme release from other hemoproteins such as myoglobin. Whether this would limit the pathological outcome of diseases associated with the accumulation of cell-free myoglobin, such 


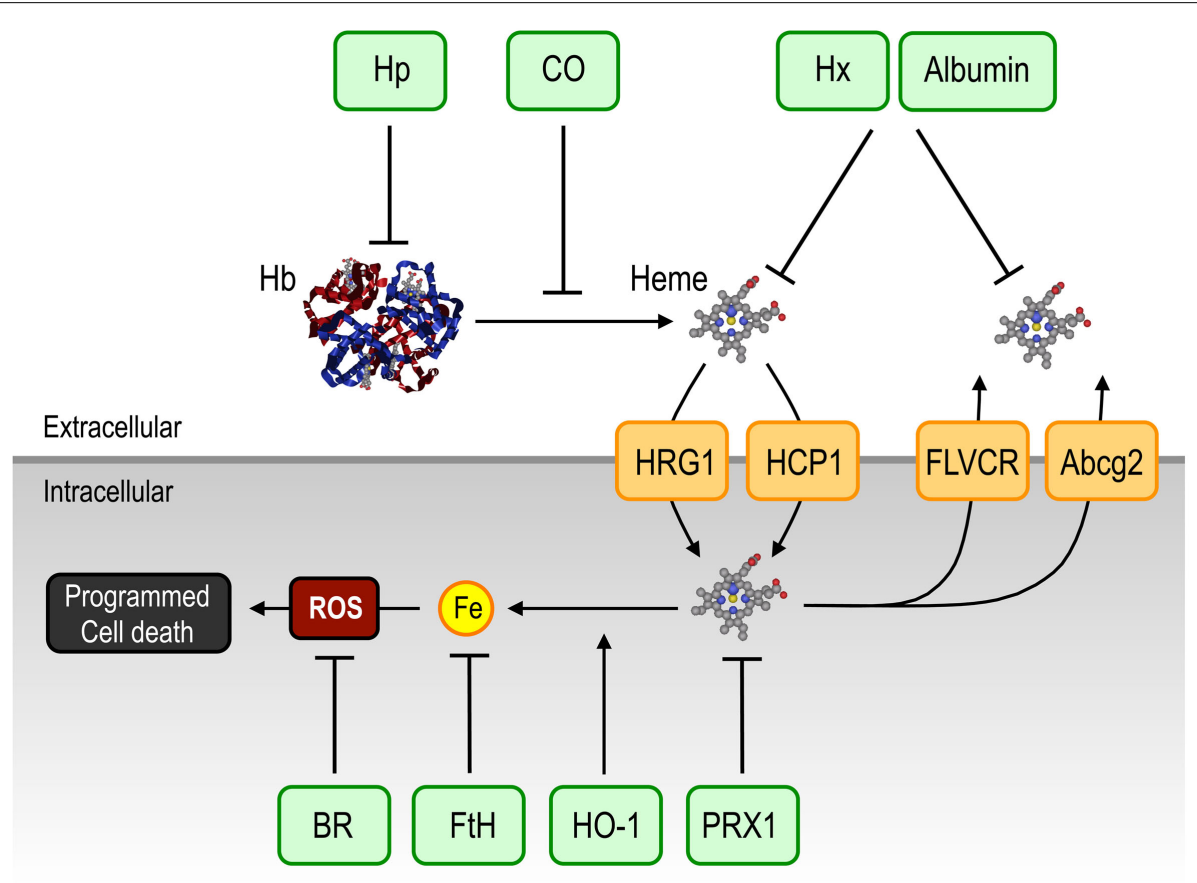

FIGURE 4 | Therapeutic targeting of free heme. Free heme, and its pathophysiological effects, might be targeted directly and indirectly, extraand intracellularly, by a range of mechanisms. Extracellularly, albumin and the two naturally occurring acute phase proteins, $\mathrm{Hp}$ and $\mathrm{Hx}$, can scavenge cell-free $\mathrm{Hb}$ and free heme, respectively, whereas $\mathrm{CO}$ can prevent the release of heme from $\mathrm{Hb}$. Intracellularly, induction of $\mathrm{HO}-1$ or $\mathrm{FtH}$, might target excess heme and labile Fe, respectively. Antioxidants such as BR and the heme carrier protein PRX1, could prevent the participation of heme-Fe in the generation of unfettered production of free radicals (ROS).
Specific heme transport between the intra- and extracellular compartments, including Abcg2, FLVCR, HCP1 and HRG-1, might be considered as potential, therapeutic targets to afford protection against heme cytotoxicity. Abbreviations: Bcrp/Abcg2, breast cancer resistance protein/ATP-binding cassette g2; BR, bilirubin; CO, carbon monoxide; Fe, iron; FLVCR, feline leukemic virus receptor; $\mathrm{FtH}$, ferritin; $\mathrm{Hb}$, hemoglobin; HCP1, heme carrier protein-1; Hp, haptoglobin; HO-1, heme oxygenase-1; HRG-1, heme responsive gene-1; Hx, hemopexin; ROS, reactive oxygen species. as during rhabdomyolysis (Kumar et al., 2009), remains to be established.

While the evidence for the therapeutic application of $\mathrm{CO}$ in a number of diseases is solid, the clinical application of this gaseous molecule poses a number of practical challenges. Recently, the development of CO-releasing molecules (CORMs) received considerable attention as an alternative means of $\mathrm{CO}$ delivery (Foresti et al., 2005; Motterlini and Otterbein, 2010). A number of studies have demonstrated that the therapeutic benefits of CORMs mimic or can even excel those of CO inhalation (Pena et al., 2012).

\section{Targeting free heme using natural heme scavengers}

Under pathologic conditions associated with severe, acute, or chronic hemolysis, as occurs under certain infectious and noninfectious inherited diseases (see Heme and the Pathogenesis of Infectious Diseases and Heme and the Pathogenesis of NonInfectious Immune-Mediated Inflammatory Conditions), the physiologic $\mathrm{Hb}$ and heme scavengers become saturated (MullerEberhard, 1970; Larsen et al., 2010). Therefore, replenishing the circulating stores of heme scavengers, thereby compensating for the loss of heme scavenging capacity in plasma, may be used as a therapeutic approach to target circulating free heme and prevent its deleterious effects.

Two clinical trials demonstrated that the administration of albumin, a heme scavenger, provides a significant survival benefit to children developing severe forms of malaria (Maitland et al., 2005; Akech et al., 2006). Similar data has recently been reported in the context of severe sepsis (Delaney et al., 2011). Whether the therapeutic benefit of albumin is due to its heme scavenging capacity remains to be established.

We have recently shown that exogenously administered $\mathrm{Hx}$ can prevent the lethal outcome of severe sepsis in mice (Larsen et al., 2010), suggesting that this may also be a viable therapeutic intervention against sepsis and possibly against other pathologies associated with a hemolytic component, such as malaria, sickle cell disease or other inherited hemolytic disorders (Figure 4).

\section{CELLULAR HEME TARGETING}

Cellular targeting of hemoproteins or heme transporters may counter the deleterious effects of intracellular accumulation of free heme and, as such, limit tissue damage and ameliorate the pathological outcome of immune-mediated inflammatory diseases. This may be accomplished by the pharmacological use of $\mathrm{CO}$ that in a similar manner to other gasotransmitters can diffuse freely into cells and, as such, target intracellular hemoproteins. In keeping with this notion, the cytoprotective effect of CO (Brouard et al., 2000) may in this manner limit tissue damage associated with the pathological outcome of immune-mediated inflammatory diseases (Otterbein et al., 2000; Fujita et al., 2001; Sato et al., 2001; Akamatsu et al., 2004; Pamplona et al., 2007; Ferreira et al., 2011). 
Given that the cytoprotective effect of $\mathrm{CO}$ acts via a mechanism targeting the mitochondria (Queiroga et al., 2010; Wang et al., 2011) it is possible that $\mathrm{CO}$ would also target mitochondrial hemoproteins that play a central role in the execution of PCD, e.g., cythocrome c.

Targeting heme transport may also be used therapeutically to prevent heme-driven tissue damage (Figure 4). This type of approach is based on the assumption that the cytotoxic effects of free heme are mediated via a mechanism that involves its transport by dedicated heme transporters. If this proves to be the case, then targeting these transporters may provide salutary effects against immune-mediated inflammatory diseases. The general principle may be that favoring the activity of heme exporters, such as FLVCR or Abcg2 may allow cells to secrete heme and, as such, to prevent its pro-oxidant effects leading to PCD and tissue damage. In a similar manner, inhibiting cellular heme import such as by targeting HRG-1 and/or HCP1 may also be used to limit intracellular heme accumulation (Figure 4; Gozzelino et al., 2010).

Finally, intracellular heme might be targeted by the modulation of HO-1 expression and/or activity. This has been shown using recombinant virus-mediated overexpression of HO-1 in animal models of disease. These include vasospasm following subarachnoid hemorrhage in rats (Ono et al., 2002), transplantation of myogenic precursor cells in pigs (Laumonier et al., 2008), IRI following liver transplant in rats (Coito et al., 2002), hyperoxiainduced lung injury in rats (Otterbein et al., 1999a), and atherosclerotic diseases (Stocker and Perrella, 2006), as reviewed in (Abraham et al., 2007).

Alternatively, the deleterious effects of cellular heme can be neutralized by the therapeutic induction of endogenous $\mathrm{HO}-1$, via the delivery of non-cytotoxic levels of heme or heme-containing proteins, e.g., by so-called preconditioning. In this manner, the administration of $\mathrm{Hb}$ in rats prior to challenge, was shown to improve survival in response to endotoxic shock (Otterbein et al., 1995), liver injury and kidney failure following rhabdomyolysis (Nath et al., 1992). Interestingly, a physiological example of heme

\section{REFERENCES}

Abraham, N. G., Asija, A., Drummond, G., and Peterson, S. (2007). Heme oxygenase -1 gene therapy: recent advances and therapeutic applications. Curr. Gene Ther. 7, 89-108.

Ahmed, A., Rahman, M., Zhang, X., Acevedo, C. H., Nijjar, S., Rushton, I., Bussolati, B., and St John, J. (2000). Induction of placental heme oxygenase- 1 is protective against TNFalpha-induced cytotoxicity and promotes vessel relaxation. Mol. Med. 6, 391-409.

Akamatsu, Y., Haga, M., Tyagi, S., Yamashita, K., Graca-Souza, A. V., Ollinger, R., Czismadia, E., May, G. A., Ifedigbo, E., Otterbein, L. E., Bach, F. H., and Soares, M. P. (2004). Heme oxygenase-1-derived carbon monoxide protects hearts from transplant associated ischemia reperfusion injury. FASEB J. 18, 771-772.
Akech, S., Gwer, S., Idro, R., Fegan, G., M., and Maitland, K. (2006). Volume expansion with albumin compared to gelofusine in children with severe malaria: results of a controlled trial. PLoS Clin. Trials 1, e21. doi:10.1371/journal.pctr.0010021

Alam, J., Cai, J., and Smith, A. (1994). Isolation and characterization of the mouse heme oxygenase1 gene. Distal $5^{\prime}$ sequences are required for induction by heme or heavy metals. J. Biol. Chem. 269, 1001-1009.

Alam, J., Camhi, S., and Choi, A. M. (1995). Identification of a second region upstream of the mouse heme oxygenase-1 gene that functions as a basal level and inducerdependent transcription enhancer. J. Biol. Chem. 270, 11977-11984.

Alam, J., and Cook, J. L. (2007). How many transcription factors does it Eziefula, A. C., Newton, C. R., Levin,

preconditioning is represented by sickle cell trait, in which individuals carry the HbS mutation (see Sickle Cell Disease) in the heterozygous form (Williams et al., 2005a,b; Jallow et al., 2009). This mutation confers protection against severe forms of malaria due to the continuous release of low concentrations of heme into circulation, thereby leading to induction of endogenous HO-1 expression and protection against Plasmodium infection (Ferreira et al., 2011).

\section{CONCLUSION}

Although not highly cytotoxic per se, free heme sensitizes nonhematopoietic cells to undergo PCD in response to a variety of pro-inflammatory agonists. This unique pathophysiologic feature relies on the capacity of heme to promote the production of free radicals in an unfettered manner. Several protection mechanisms, regulating heme synthesis, catabolism and transport, can be considered as possible therapeutic targets to prevent the deleterious effects of free heme. In keeping with this notion, tissue damage control afforded by genes involved in heme and Fe metabolism, such as HO-1 and FtH, provide a "proof of principle" for the therapeutic benefits associated with neutralization of hemeFe cytotoxicity in the context of immune-mediated inflammatory diseases.

\section{ACKNOWLEDGMENTS}

The authors thank Ana Cunha (Instituto Gulbenkian de Ciência, Oeiras, Portugal) for carefully reading the manuscript and providing critical comments. This work was funded by Fundação para a Ciência e Tecnologia (FCT, Portugal) grants to RL (SFRH/BPD/25436/2005), ZG (SFRH/BD/44828/2008) and RG (SFRH/BPD/44256/2008), MPS was funded by FCT (PTDC/BIA-BCM/101311/2008， PTDC/SAU-FCF/100762/2008 and PTDC/SAU-TOX/116627/2010), the European Community, 6th Framework, Grant LSH-2005-1.2.5-1, XENOME, and The Bill \& Melinda Gates Foundation.

take to turn on the heme oxygenase1 gene? Am. J. Respir. Cell. Mol. Biol. 36, 166-174.

Alam, J., and Smith, A. (1989). Receptormediated transport of heme by hemopexin regulates gene expression in mammalian cells. J. Biol. Chem. 264, 17637-17640.

Allen, J. W., Daltrop, O., Stevens, J. M., and Ferguson, S. J. (2003). Ctype cytochromes: diverse structures and biogenesis systems pose evolutionary problems. Philos. Trans. R. Soc. Lond. B Biol. Sci. 358, 255-266.

Allhorn, M., Berggard, T., Nordberg, J., Olsson, M. L., and Akerstrom, B. (2002). Processing of the lipocalin alpha(1)-microglobulin by hemoglobin induces heme-binding and heme-degradation properties. Blood 99, 1894-1901.

Andrade, B. B., Araujo-Santos, T., Luz, N. F., Khouri, R., Bozza, M. T.
Camargo, L. M., Barral, A., Borges, V. M., and Barral-Netto, M. (2010a). Heme impairs prostaglandin E2 and TGF-beta production by human mononuclear cells via $\mathrm{Cu} / \mathrm{Zn}$ superoxide dismutase: insight into the pathogenesis of severe malaria. $J$. Immunol. 185, 1196-1204.

Andrade, B. B., Reis-Filho, A., SouzaNeto, S. M., Clarencio, J., Camargo, L. M., Barral, A., and BarralNetto, M. (2010b). Severe Plasmodium vivax malaria exhibits marked inflammatory imbalance. Malar. J. 9 , 13.

Antosiewicz, J., Ziolkowski, W., Kaczor, J. J., and Herman-Antosiewicz, A. (2007). Tumor necrosis factoralpha-induced reactive oxygen species formation is mediated by JNK1-dependent ferritin degradation and elevation of labile iron pool. Free Radic. Biol. Med. 43, 265-270. 
Aono, S. (2008). Metal-containing sensor proteins sensing diatomic gas molecules. Dalton Trans. 24, 3137-3146.

Azuma, M., Kabe, Y., Kuramori, C., Kondo, M., Yamaguchi, Y., and Handa, H. (2008). Adenine nucleotide translocator transports haem precursors into mitochondria. PLoS ONE 3, e3070. doi:10.1371/journal.pone.0003070

Badyal, S. K., Joyce, M. G., Sharp, K. H., Seward, H. E., Mewies, M., Basran, J., Macdonald, I. K., Moody, P. C., and Raven, E. L. (2006). Conformational mobility in the active site of a heme peroxidase. J. Biol. Chem. 281, 24512-24520.

Bain, B. J. (2005). Diagnosis from the blood smear. N. Engl. J. Med. 353, 498-507.

Baker, H. M., Anderson, B. F., and Baker, E. N. (2003). Dealing with iron: common structural principles in proteins that transport iron and heme. Proc. Natl. Acad. Sci. U.S.A. 100, 3579-3583.

Balla, G., Jacob, H. S., Balla, J., Rosenberg, M., Nath, K., Apple, F., Eaton, J. W., and Vercellotti, G. M. (1992). Ferritin: a cytoprotective antioxidant strategem of endothelium. J. Biol. Chem. 267, 18148-18153.

Balla, G., Jacob, H. S., Eaton, J. W., Belcher, J. D., and Vercellotti, G. M. (1991). Hemin: a possible physiological mediator of low density lipoprotein oxidation and endothelial injury. Arterioscler. Thromb. 11, 1700-1711.

Balla, J., Jacob, H. S., Balla, G., Nath, K., Eaton, J. W., and Vercellotti, G. M. (1993). Endothelialcell heme uptake from heme proteins: induction of sensitization and desensitization to oxidant damage. Proc. Natl. Acad. Sci. U.S.A. 90, 9285-9289.

Baranano, D. E., Rao, M., Ferris, C. D., and Snyder, S. H. (2002). Biliverdin reductase: a major physiologic cytoprotectant. Proc. Natl. Acad. Sci. U.S.A. 99, 16093-16098.

Baranano, D. E., Wolosker, H., Bae, B. I., Barrow, R. K., Snyder, S. H., and Ferris, C. D. (2000). A mammalian iron ATPase induced by iron. J. Biol. Chem. 275, 15166-15173.

Barber, A., Robson, S. C., Myatt, L., Bulmer, J. N., and Lyall, F. (2001). Heme oxygenase expression in human placenta and placental bed: reduced expression of placenta endothelial HO-2 in preeclampsia and fetal growth restriction. FASEB J. 15, 1158-1168.

Battistuzzi, G., Bellei, M., Bortolotti, C. A., and Sola, M. (2010). Redox properties of heme peroxidases. Arch. Biochem. Biophys. 500, 21-36.

Belcher, J. D., Bryant, C. J., Nguyen, J., Bowlin, P. R., Kielbik, M. C., Bischof, J. C., Hebbel, R. P., and Vercellotti, G. M. (2003). Transgenic sickle mice have vascular inflammation. Blood 101, 3953-3959.

Belcher, J. D., Mahaseth, H., Welch, T. E., Otterbein, L. E., Hebbel, R. P., and Vercellotti, G. M. (2006). Heme oxygenase- 1 is a modulator of inflammation and vaso-occlusion in transgenic sickle mice. J. Clin. Invest. 116, 808-816.

Berberat, P. O., Katori, M., Kaczmarek, E., Anselmo, D., Lassman, C., Ke, B. Shen, X., Busuttil, R. W., Yamashita, K., Csizmadia, E., Tyagi, S., Otterbein, L. E., Brouard, S., Tobiasch, E., Bach, F. H., Kupiec-Weglinski, J. W., and Soares, M. P. (2003). Heavy chain ferritin acts as an antiapoptotic gene that protects livers from ischemia reperfusion injury. FASEB J. 17, 1724-1726.

Bernhardt, R. (1996). Cytochrome P450: structure, function, and generation of reactive oxygen species. Rev. Physiol. Biochem. Pharmacol. 127, 137-221.

Bishop, A., Yet, S. F., Lee, M. E., Perrella, M. A., and Demple, B. (2004). A key role for heme oxygenase-1 in nitric oxide resistance in murine motor neurons and glia. Biochem. Biophys. Res. Commun. 325, 3-9.

Bowman, S. E., and Bren, K. L. (2008). The chemistry and biochemistry of heme c: functional bases for covalent attachment. Nat. Prod. Rep. 25, 1118-1130.

Brouard, S., Berberat, P. O., Tobiasch, E., Seldon, M. P., Bach, F. H., and Soares, M. P. (2002). Heme oxygenase-1-derived carbon monoxide requires the activation of transcription factor NF-kappa B to protect endothelial cells from tumor necrosis factor-alpha-mediated apoptosis. J. Biol. Chem. 277, 17950-17961.

Brouard, S., Otterbein, L. E., Anrather, J., Tobiasch, E., Bach, F. H., Choi, A M., and Soares, M. P. (2000). Carbon monoxide generated by heme oxygenase 1 suppresses endothelial cell apoptosis. J. Exp. Med. 192, 1015-1026.

Brune, B., and Ullrich, V. (1987). Inhibition of platelet aggregation by carbon monoxide is mediated by activation of guanylate cyclase. Mol. Pharmacol. 32, 497-504.

Bruns, G. P., and London, I. M. (1965). The effect of hemin on the synthesis of globin. Biochem. Biophys. Res. Commun. 18, 236-242.
Bunn, H. F., and Jandl, J. H. (1966) Exchange of heme among hemoglobin molecules. Proc Natl. Acad. Sci. U.S.A. 56, 974-978.

Bunn, H. F., and Jandl, J. H. (1968). Exchange of heme among hemoglobins and between hemoglobin and albumin. J. Biol. Chem. 243, 465-475.

Bushnell, G. W., Louie, G. V., and Brayer, G. D. (1990). High-resolution threedimensional structure of horse heart cytochrome c. J. Mol. Biol. 214 585-595.

Camejo, G., Halberg, C., ManschikLundin, A., Hurt-Camejo, E., Rosengren, B., Olsson, H., Hansson, G. I., Forsberg, G. B., and Ylhen, B. (1998). Hemin binding and oxidation of lipoproteins in serum: mechanisms and effect on the interaction of LDL with human macrophages. $J$. Lipid Res. 39, 755-766.

Cappellini, M. D., and Fiorelli, G. (2008). Glucose-6-phosphate dehydrogenase deficiency. Lancet 371, 64-74.

Caughey, W. S., Smythe, G. A., O'Keeffe, D. H., Maskasky, J. E., and Smith, M. I. (1975). Heme A of cytochrome c oxicase. Structure and properties: comparisons with hemes $\mathrm{B}, \mathrm{C}$, and S and derivatives. J. Biol. Chem. 250, 7602-7622.

Chapman, S. K., Daff, S., and Munro, A. W. (1997). Heme: the most versatile redox centre in biology? Metal Sites Proteins Models 88, 39-70.

Chay, T. R., and Brillhart, D. (1974a). Mechanism of cooperative oxygen binding to hemoglobin: kinetic aspects. Biochemistry 13, 5311-5317.

Chay, T. R., and Brillhart, D. K. (1974b). Mechanism of cooperative oxygen binding to hemoglobin: equilibrium aspects. Biochemistry 13, 4579-4585.

Choi, A. M., and Alam, J. (1996) Heme oxygenase-1: function, regulation, and implication of a novel stress-inducible protein in oxidantinduced lung injury. Am. J. Respir. Cell Mol. Biol. 15, 9-19.

Cohen, J. (2002). The immunopathogenesis of sepsis. Nature 420, 885-891.

Cohen, J., and Carlet, J. (1996). INTERSEPT: an international, multicenter, placebo-controlled trial of monoclonal antibody to human tumor necrosis factor-alpha in patients with sepsis. International Sepsis Trial Study Group. Crit. Care Med. 24, 1431-1440.

Coito, A. J., Buelow, R., Shen, X. D., Amersi, F., Moore, C., Volk, H. D., Busuttil, R. W., and KupiecWeglinski, J. W. (2002). Heme oxygenase-1 gene transfer inhibits inducible nitric oxide synthase expression and protects genetically fat Zucker rat livers from ischemiareperfusion injury. Transplantation 74, 96-102.

Cozzi, A., Levi, S., Corsi, B., Santambrogio, P., Campanella, A., Gerardi, G., and Arosio, P. (2003). Role of iron and ferritin in TNFalpha-induced apoptosis in HeLa cells. FEBS Lett. 537, 187-192.

Crane, B. R., Arvai, A. S., Gachhui, R., Wu, C., Ghosh, D. K., Getzoff, E. D., Stuehr, D. J., and Tainer, J. A. (1997). The structure of nitric oxide synthase oxygenase domain and inhibitor complexes. Science 278, 425-431.

Davis, R. J. (2000). Signal transduction by the JNK group of MAP kinases. Cell 103, 239-252.

Delaney, A. P., Dan, A., McCaffrey, J., and Finfer, S. (2011). The role of albumin as a resuscitation fluid for patients with sepsis: a systematic review and meta-analysis. Crit. Care Med. 39, 386-391.

Dey, A., and Ghosh, A. (2002) "True" iron(V) and iron(VI) porphyrins: a first theoretical exploration. J. Am. Chem. Soc. 124 3206-3207.

Dioum, E. M., Rutter, J., Tuckerman, J. R., Gonzalez, G., Gilles-Gonzalez, M. A., and McKnight, S. L. (2002). NPAS2: a gas-responsive transcription factor. Science 298, 2385-2387.

Dore, S., Takahashi, M., Ferris, C. D., Zakhary, R., Hester, L. D. Guastella, D., and Snyder, S. H. (1999). Bilirubin, formed by activation of heme oxygenase-2, protects neurons against oxidative stress injury. Proc. Natl. Acad. Sci. U.S.A. 96, 2445-2450.

Eisenstein, R. S., Garcia-Mayol, D., Pettingell, W., and Munro, H. N. (1991) Regulation of ferritin and heme oxygenase synthesis in rat fibroblasts by different forms of iron. Proc. Natl. Acad. Sci. U.S.A. 88, 688-692.

Eskew, J. D., Vanacore, R. M., Sung, L., Morales, P. J., and Smith, A. (1999). Cellular protection mechanisms against extracellular heme. heme-hemopexin, but not free heme, activates the N-terminal c-jun kinase. J. Biol. Chem. 274, 638-648.

Evans, S. V., and Brayer, G. D. (1988). Horse heart metmyoglobin. A 2.8-A resolution three-dimensional structure determination. J. Biol. Chem. 263, 4263-4268.

Evans, S. V., and Brayer, G. D. (1990). High-resolution study of the threedimensional structure of horse heart metmyoglobin. J. Mol. Biol. 213, 885-897. 
Faller, M., Matsunaga, M., Yin, S., Loo, J. A., and Guo, F. (2007). Heme is involved in microRNA processing. Nat. Struct. Mol. Biol. 14, 23-29.

Fasano, M., Fanali, G., Leboffe, L., and Ascenzi, P. (2007). Heme binding to albuminoid proteins is the result of recent evolution. IUBMB Life 59, 436-440.

Fenton, H. J. H. (1894). Oxidation of tartaric acid in presence of iron. $J$. Chem. Soc. Trans. 65, 899-911.

Fermi, G., Perutz, M. F., Shaanan, B., and Fourme, R. (1984). The crystal structure of human deoxyhaemoglobin at 1.74 A resolution. J. Mol. Biol. 175, 159-174.

Fernandez, P. L., Dutra, F. F., Alves, L., Figueiredo, R. T., Mourao-Sa, D., Fortes, G. B., Bergstrand, S., Lonn, D., Cevallos, R. R., Pereira, R. M., Lopes, U. G., Travassos, L. H., Paiva, C. N., and Bozza, M. T. (2010). Heme amplifies the innate immune response to microbial molecules through spleen tyrosine kinase (Syk)-dependent reactive oxygen species generation. J. Biol. Chem. 285, 32844-32851.

Ferreira, A., Balla, J., Jeney, V., Balla, G., and Soares, M. P. (2008). A central role for free heme in the pathogenesis of severe malaria: the missing link? J. Mol. Med. 86, 1097-1111.

Ferreira, A., Marguti, I., Bechmann, I., Jeney, V., Chora, A., Palha, N. R., Rebelo, S., Henri, A., Beuzard, Y., and Soares, M. P. (2011). Sickle hemoglobin confers tolerance to Plasmodium infection. Cell 145, 398-409.

Ferris, C. D., Jaffrey, S. R., Sawa, A., Takahashi, M., Brady, S. D., Barrow, R. K., Tysoe, S. A., Wolosker, H., Baranano, D. E., Dore, S., Poss, K. D., and Snyder, S. H. (1999). Haem oxygenase-1 prevents cell death by regulating cellular iron. Nat. Cell Biol. 1, 152-157.

Figueiredo, R. T., Fernandez, P. L., Mourao-Sa, D. S., Porto, B. N., Dutra, F. F., Alves, L. S., Oliveira, M. F., Oliveira, P. L., Graca-Souza, A. V., and Bozza, M. T. (2007). Characterization of heme as activator of Toll-like receptor 4. J. Biol. Chem. 282, 20221-20229.

Flower, D. R., North, A. C., and Sansom, C. E. (2000). The lipocalin protein family: structural and sequence overview. Biochim. Biophys. Acta 1482, 9-24.

Foresti, R., Shurey, C., Ansari, T., Sibbons, P., Mann, B. E., Johnson, T. R., Green, C. J., and Motterlini, R. (2005). Reviewing the use of carbon monoxide-releasing molecules (CO-RMs) in biology: implications in endotoxin-mediated vascular dysfunction. Cell. Mol. Biol. 51, 409-423.

Fortes, G. B., Alves, L. S., de Oliveira, R., Dutra, F. F., Rodrigues, D., Fernandez, P. L., Souto-Padron, T., De Rosa, M. J., Kelliher, M., Golenbock, D., Chan, F. K., and Bozza, M. T. (2012). Heme induces programmed necrosis on macrophages through autocrine TNF and ROS production. Blood 119, 2368-2375.

Francis, S. E., Sullivan, D. J. Jr., and Goldberg, D. E. (1997). Hemoglobin metabolism in the malaria parasite Plasmodium falciparum. Annu. Rev. Microbiol. 51, 97-123.

Fufezan, C., Zhang, J., and Gunner, M. R. (2008). Ligand preference and orientation in b- and c-type heme-binding proteins. Proteins 73 , 690-704.

Fujita, T., Toda, K., Karimova, A., Yan, S. F., Naka, Y., Yet, S. F., and Pinsky, D. J. (2001). Paradoxical rescue from ischemic lung injury by inhaled carbon monoxide driven by derepression of fibrinolysis. Nat. Med. 7, 598-604.

Gozzelino, R., Jeney, V., and Soares, M. P. (2010). Mechanisms of cell protection by heme oxygenase-1. Annu. Rev. Pharmacol. Toxicol. 50, 323-354.

Gozzelino, R., and Soares, M. P. (2011). Heme sensitization to TNFmediated programmed cell death. Adv. Exp. Med. Biol. 691, 211-219.

Graber, S. G., and Woodworth, R. C. (1986). Myoglobin expression in L6 muscle cells. Role of differentiation and heme. J. Biol. Chem. 261, 9150-9154.

Gray, H. B., and Winkler, J. R. (1996). Electron transfer in proteins. Annu. Rev. Biochem. 65, 537-561.

Gutierrez, A., Florencio, R., Ezpeleta, C., Cisterna, R., and Martinez, M. (1995). Fatal intravascular hemolysis in a patient with Clostridium perfringens septicemia. Clin. Infect. Dis. 20, 1064-1065.

Hamilton, J. W., Bement, W. J., Sinclair, P. R., Sinclair, J. F., Alcedo, J. A., and Wetterhahn, K. E. (1991). Heme regulates hepatic 5aminolevulinate synthase mRNA expression by decreasing mRNA half-life and not by altering its rate of transcription. Arch. Biochem. Biophys. 289, 387-392.

Han, S. W., Ching, Y. C., Hammes, S. L. and Rousseau, D. L. (1991). Vibrational structure of the formyl group on heme a. Implications on the properties of cytochrome c oxidase. Biophys. J. 60, 45-52.

Harrison, P. M., and Arosio, P. (1996). The ferritins: molecular properties, iron storage function and cellular regulation. Biochim. Biophys. Acta 1275, 161-203.

Hebbel, R. P., Morgan, W. T., Eaton, J. W., and Hedlund, B. E. (1988). Accelerated autoxidation and heme loss due to instability of sickle hemoglobin. Proc. Natl. Acad. Sci. U.S.A. 85, 237-241.

Heinemann, I. U., Jahn, M., and Jahn, D. (2008). The biochemistry of heme biosynthesis. Arch. Biochem. Biophys. 474, 238-251.

Hira, S., Tomita, T., Matsui, T., Igarashi, K., and Ikeda-Saito, M. (2007). Bach1, a heme-dependent transcription factor, reveals presence of multiple heme binding sites with distinct coordination structure. IUBMB Life 59, 542-551.

Horrigan, F. T., Heinemann, S. H., and Hoshi, T. (2005). Heme regulates allosteric activation of the Slo1 BK channel. J. Gen. Physiol. 126, 7-21.

Hotchkiss, R. S., and Karl, I. E. (2003). The pathophysiology and treatment of sepsis. N. Engl. J. Med. 348, 138-150.

Hutagalung, R., Wilairatana, P., Looareesuwan, S., Brittenham, G. M., Aikawa, M., and Gordeuk, V. R. (1999). Influence of hemoglobin E trait on the severity of Falciparum malaria. J. Infect. Dis. 179, 283-286.

Hvidberg, V., Maniecki, M. B., Jacobsen, C., Hojrup, P., Moller, H. J., and Moestrup, S. K. (2005). Identification of the receptor scavenging hemopexin-heme complexes. Blood 106, 2572-2579.

Idro, R., Jenkins, N. E., and Newton, C. R. (2005). Pathogenesis, clinical features, and neurological outcome of cerebral malaria. Lancet Neurol. 4 827-840.

Igarashi, K., and Sun, J. (2006). The heme-Bach1 pathway in the regulation of oxidative stress response and erythroid differentiation. Antioxid. Redox Signal. 8, 107-118.

Ihara, N., Akagi, R., Ejiri, K., Kudo, T., Furuyama, K., and Fujita, H. (1998). Developmental changes of gene expression in heme metabolic enzymes in rat placenta. FEBS Lett. 439, 163-167.

Immenschuh, S., Fahimi, H. D., and Baumgart-Vogt, E. (2005). Complementary regulation of heme oxygenase- 1 and peroxiredoxin I gene expression by oxidative stress in the liver. Cell. Mol. Biol. 51, 471-477. Immenschuh, S., Iwahara, S., Satoh, H., Nell, C., Katz, N., and MullerEberhard, U. (1995). Expression of the mRNA of heme-binding protein 23 is coordinated with that of heme oxygenase- 1 by heme and heavy metals in primary rat hepatocytes and hepatoma cells. Biochemistry 34, 13407-13411.

Jallow, M., Teo, Y. Y., Small, K. S., Rockett, K. A., Deloukas, P., Clark, T. G., Kivinen, K., Bojang, K. A., Conway, D. J., Pinder, M., Sirugo, G., SisayJoof, F., Usen, S., Auburn, S., Bumpstead, S. J., Campino, S., Coffey, A., Dunham, A., Fry, A. E., Green, A., Gwilliam, R., Hunt, S. E., Inouye, M., Jeffreys, A. E., Mendy, A., Palotie, A., Potter, S., Ragoussis, J., Rogers, J., Rowlands, K., Somaskantharajah, E., Whittaker, P., Widden, C., Donnelly, P., Howie, B., Marchini, J., Morris, A., SanJoaquin, M., Achidi, E. A., Agbenyega, T., Allen, A., Amodu, O., Corran, P., Djimde, A., Dolo, A. Doumbo, O. K., Drakeley, C., Dunstan, S., Evans, J., Farrar, J., Fernando, D., Hien, T. T., Horstmann, R. D., Ibrahim, M., Karunaweera, N., Kokwaro, G., Koram, K. A., Lemnge, M., Makani, J., Marsh, K., Michon, P., Modiano, D., Molyneux, M. E., Mueller, I., Parker, M., Peshu, N., Plowe, C. V., Puijalon, O., Reeder, J., Reyburn, H., Riley, E. M., Sakuntabhai, A., Singhasivanon, P., Sirima, S., Tall, A., Taylor, T. E., Thera, M., Troye-Blomberg, M., Williams, T. N., Wilson, M., and Kwiatkowski, D. P. (2009). Genome-wide and fineresolution association analysis of malaria in West Africa. Nat. Genet. 41, 657-665.

Jeney, V., Balla, J., Yachie, A., Varga, Z., Vercellotti, G. M., Eaton, J. W., and Balla, G. (2002). Pro-oxidant and cytotoxic effects of circulating heme. Blood 100, 879-887.

Jeong, J., Rouault, T. A., and Levine, R. L. (2004). Identification of a heme-sensing domain in iron regulatory protein 2. J. Biol. Chem. 279, 45450-45454.

Kaasik, K., and Lee, C. C. (2004). Reciprocal regulation of haem biosynthesis and the circadian clock in mammals. Nature 430, 467-471.

Kakar, S., Hoffman, F. G., Storz, J. F., Fabian, M., and Hargrove, M. S. (2010). Structure and reactivity of hexacoordinate hemoglobins. Biophys. Chem. 152, 1-14.

Kamata, H., Honda, S., Maeda, S., Chang, L., Hirata, H., and Karin, M. (2005). Reactive oxygen species promote TNFalpha-induced death and sustained JNK activation by inhibiting MAP kinase phosphatases. Cell 120, 649-661.

Karpefors, M., Adelroth, P., Namslauer, A., Zhen, Y., and Brzezinski, P. (2000). Formation of the "peroxy" intermediate in cytochrome c oxidase is associated with internal 
proton/hydrogen transfer. Biochemistry 39, 14664-14669.

Keel, S. B., Doty, R. T., Yang, Z., Quigley, J. G., Chen, J., Knoblaugh, S., Kingsley, P. D., De Domenico, I., Vaughn, M. B., Kaplan, J., Palis, J., and Abkowitz, J. L. (2008). A heme export protein is required for red blood cell differentiation and iron homeostasis. Science 319, 825-828.

Kempe, D. S., Akel, A., Lang, P. A., Hermle, T., Biswas, R., Muresanu, J., Friedrich, B., Dreischer, P., Wolz, C., Schumacher, U., Peschel, A., Gotz, F., Doring, G., Wieder, T., Gulbins, E., and Lang, F. (2007). Suicidal erythrocyte death in sepsis. J. Mol. Med. 85, 273-281.

Khan, A. A., and Quigley, J. G. (2011). Control of intracellular heme levels: heme transporters and heme oxygenases. Biochim. Biophys. Acta 1813, 668-682.

Kim, H. P., Ryter, S. W., and Choi, A. M. (2006). CO as a cellular signaling molecule. Annu. Rev. Pharmacol. Toxicol. 46, 411-449.

Krishnamurthy, P., Ross, D. D., Nakanishi, T., Bailey-Dell, K., Zhou, S., Mercer, K. E., Sarkadi, B., Sorrentino, B. P., and Schuetz, J. D. (2004). The stem cell marker Bcrp/ABCG2 enhances hypoxic cell survival through interactions with heme. $J$. Biol. Chem. 279, 24218-24225.

Krishnamurthy, P., and Schuetz, J. D. (2006). Role of ABCG2/BCRP in biology and medicine. Annu. Rev. Pharmacol. Toxicol. 46, 381-410.

Krishnamurthy, P. C., Du, G., Fukuda, Y., Sun, D., Sampath, J., Mercer, K. E., Wang, J., Sosa-Pineda, B., Murti, K. G., and Schuetz, J. D. (2006). Identification of a mammalian mitochondrial porphyrin transporter. Nature 443, 586-589.

Kristiansen, M., Graversen, J. H., Jacobsen, C., Sonne, O., Hoffman, H. J., Law, S. K., and Moestrup, S. K. (2001). Identification of the haemoglobin scavenger receptor. Nature 409, 198-201.

Kumar, A. A., Bhaskar, E., Palamaner Subash Shantha, G., Swaminathan, P., and Abraham, G. (2009). Rhabdomyolysis in community acquired bacterial sepsis-a retrospective cohort study. PLoS ONE 4, e7182. doi:10.1371/journal.pone.0007182

Kumar, S., and Bandyopadhyay, U. (2005). Free heme toxicity and its detoxification systems in human. Toxicol. Lett. 157, 175-188.

Kutty, R. K., and Maines, M. D. (1981). Purification and characterization of biliverdin reductase from rat liver. $J$. Biol. Chem. 256, 3956-3962.
Lad, L., Schuller, D. J., Shimizu, H., Friedman, J., Li, H., Ortiz de Montellano, P. R., and Poulos, T. L. (2003). Comparison of the hemefree and -bound crystal structures of human heme oxygenase-1. J. Biol. Chem. 278, 7834-7843.

Lang, F., Gulbins, E., Lerche, H., Huber, S. M., Kempe, D. S., and Foller, M. (2008). Eryptosis, a window to systemic disease. Cell. Physiol. Biochem. 22, 373-380.

Larsen, R., Gozzelino, R., Jeney, V., Tokaji, L., Bozza, F. A., Japiassu, A. M., Bonaparte, D., Cavalcante, M. M., Chora, A., Ferreira, A., Marguti, I., Cardoso, S., Sepulveda, N., Smith, A., and Soares, M. P. (2010). A central role for free heme in the pathogenesis of severe sepsis. Sci. Transl. Med. 2, 51 ra71.

Lathrop, J. T., and Timko, M. P. (1993). Regulation by heme of mitochondrial protein transport through a conserved amino acid motif. Science 259, 522-525.

Latunde-Dada, G. O., Takeuchi, K., Simpson, R. J., and McKie, A. T. (2006). Haem carrier protein 1 (HCP1): expression and functional studies in cultured cells. FEBS Lett. 580, 6865-6870.

Laumonier, T., Yang, S., Konig, S., Chauveau, C., Anegon, I., Hoffmeyer, P., and Menetrey, J. (2008). Lentivirus mediated HO-1 gene transfer enhances myogenic precursor cell survival after autologous transplantation in pig. Mol. Ther. 16, 404-410.

Levy, A. P., Asleh, R., Blum, S., Levy, N. S., Miller-Lotan, R., Kalet-Litman, S., Anbinder, Y., Lache, O., Nakhoul, F. M., Asaf, R., Farbstein, D., Pollak, M., Soloveichik, Y. Z., Strauss, M., Alshiek, J., Livshits, A., Schwartz, A., Awad, H., Jad, K., and Goldenstein, H. (2010). Haptoglobin: basic and clinical aspects. Antioxid. Redox Signal. 12, 293-304.

Li, T., Bonkovsky, H. L., and Guo, J. T. (2011). Structural analysis of heme proteins: implications for design and prediction. BMC Struct. Biol. 11, 13. doi:10.1186/1472-6807-11-13

Little, H. N., and Neilands, J. B. (1960). Binding of haematin by human serum albumin. Nature 188, 913-915.

Ma, X., Sayed, N., Beuve, A., and van den Akker, F. (2007). NO and CO differentially activate soluble guanylyl cyclase via a heme pivot-bend mechanism. EMBO J. 26, 578-588.

Maines, M. D., Trakshel, G. M., and Kutty, R. K. (1986). Characterization of two constitutive forms of rat liver microsomal heme oxygenase.
Only one molecular species of the enzyme is inducible. J. Biol. Chem. 261, 411-419.

Maitland, K., and Marsh, K. (2004) Pathophysiology of severe malaria in children. Acta Trop. 90, 131-140.

Maitland, K., Pamba, A., English, M., Peshu, N., Marsh, K., Newton, C. and Levin, M. (2005). Randomized trial of volume expansion with albumin or saline in children with severe malaria: preliminary evidence of albumin benefit. Clin. Infect. Dis. 40, 538-545.

Makinen, M. W., Schichman, S. A. Hill, S. C., and Gray, H. B. (1983). Heme-heme orientation and electron transfer kinetic behavior of multisite oxidation-reduction enzymes. Science 222, 929-931.

Marsh, K., Forster, D., Waruiru, C. Mwangi, I., Winstanley, M., Marsh, V., Newton, C., Winstanley, P., Warn, P., Peshu, N., Pasvol, G., and Snow, R. (1995). Indicators of life-threatening malaria in African children. N. Engl. J. Med. 332, 1399-1404.

Mason, P. J. (1996). New insights into G6PD deficiency. Br. J. Haematol. 94, 585-591.

Masuda, K., Shima, H., Watanabe, M. and Kikuchi, K. (2001). MKP-7, a novel mitogen-activated protein kinase phosphatase, functions as a shuttle protein. J. Biol. Chem. 276, 39002-39011.

Medzhitov, R., Schneider, D. S., and Soares, M. P. (2012). Disease tolerance as a defense strategy. Science 335, 936-941.

Meier, M., Janosik, M., Kery, V., Kraus, J. P., and Burkhard, P. (2001). Structure of human cystathionine betasynthase: a unique pyridoxal $5^{\prime}$ phosphate-dependent heme protein. EMBO J. 20, 3910-3916.

Melamed-Frank, M., Lache, O., Enav, B. I., Szafranek, T., Levy, N. S., Ricklis, R. M., and Levy, A. P. (2001). Structure-function analysis of the antioxidant properties of haptoglobin. Blood 98, 3693-3698.

Miller, L. H., Baruch, D. I., Marsh, K., and Doumbo, O. K. (2002). The pathogenic basis of malaria. Nature 415, 673-679.

Miller, Y. I., and Shaklai, N. (1999). Kinetics of hemin distribution in plasma reveals its role in lipoprotein oxidation. Biochim. Biophys. Acta 1454, 153-164.

Mirkin, N., Jaconcic, J., Stojanoff, V., and Moreno, A. (2008). High resolution $\mathrm{X}$-ray crystallographic structure of bovine heart cytochrome $\mathrm{c}$ and its application to the design of an electron transfer biosensor. Proteins 70 83-92.
Miyatake, T., Koyamada, N., Hancock, W. W., Soares, M. P., and Bach, F. H. (1998). Survival of accommodated cardiac xenografts upon retransplantation into cyclosporinetreated recipients. Transplantation $65,1563-1569$

Modiano, D., Luoni, G., Sirima, B. S., Simpore, J., Verra, F., Konate, A., Rastrelli, E., Olivieri, A., Calissano, C., Paganotti, G. M., D'Urbano, L., Sanou, I., Sawadogo, A., Modiano, G., and Coluzzi, M. (2001). Haemoglobin $\mathrm{C}$ protects against clinical Plasmodium falciparum malaria. Nature 414, 305-308.

Morgan, W. T., Liem, H. H., Sutor, R. P., and Muller-Ebergard, U. (1976) Transfer of heme from hemealbumin to hemopexin. Biochim. Biophys. Acta 444, 435-445.

Motterlini, R., and Otterbein, L. E. (2010). The therapeutic potential of carbon monoxide. Nat. Rev. Drug Discov. 9, 728-743.

Muller-Eberhard, U. (1970). Hemopexin. N. Engl. J. Med. 283, 1090-1094.

Muller-Eberhard, U., Javid, J., Liem, H. H., Hanstein, A., and Hanna, M. (1968). Plasma concentrations of hemopexin, haptoglobin and heme in patients with various hemolytic diseases. Blood 32, 811-815.

Murray, C. J., Rosenfeld, L. C., Lim, S. S. Andrews, K. G., Foreman, K. J., Haring, D., Fullman, N., Naghavi, M., Lozano, R., and Lopez, A. D. (2012). Global malaria mortality between 1980 and 2010: a systematic analysis. Lancet 379, 413-431.

Mustafa, A. K., Gadalla, M. M., and Snyder, S. H. (2009). Signaling by gasotransmitters. Sci. Signal. 2, re2.

Nagababu, E., and Rifkind, J. M. (2000). Heme degradation during autoxidation of oxyhemoglobin. Biochem. Biophys. Res. Commun. 273, 839-845.

Nagababu, E., and Rifkind, J. M. (2004). Heme degradation by reactive oxygen species. Antioxid. Redox Signal. 6, 967-978.

Nath, K. A., Balla, G., Vercellotti, G. M., Balla, J., Jacob, H. S., Levitt, M. D., and Rosenberg, M. E. (1992). Induction of heme oxygenase is a rapid, protective response in rhabdomyolysis in the rat. J. Clin. Invest. 90, 267-270.

Ogura, T., Hirota, S., Proshlyakov, D. A., ShinzawaItoh, K., Yoshikawa, S., and Kitagawa, T. (1996). Time-resolved resonance Raman evidence for tight coupling between electron transfer and proton pumping of cytochrome $c$ oxidase upon the change from the Fe-V oxidation level to the Fe-IV 
oxidation level. J. Am. Chem. Soc. 118, 5443-5449.

Ollinger, R., Bilban, M., Erat, A., Froio, A., McDaid, J., Tyagi, S., Csizmadia, E., Graca-Souza, A. V., Liloia, A., Soares, M. P., Otterbein, L. E., Usheva, A., Yamashita, K., and Bach, F. H. (2005). Bilirubin: a natural inhibitor of vascular smooth muscle cell proliferation. Circulation 112, 1030-1039.

Ollinger, R., Wang, H., Yamashita, K., Wegiel, B., Thomas, M., Margreiter, R., and Bach, F. H. (2007). Therapeutic applications of bilirubin and biliverdin in transplantation. Antioxid. Redox Signal. 9, 2175-2185.

Ono, S., Komuro, T., and Macdonald, R. L. (2002). Heme oxygenase-1 gene therapy for prevention of vasospasm in rats. J. Neurosurg. 96, 1094-1102.

Opal, S. M., Fisher, C. J. Jr., Dhainaut, J. F., Vincent, J. L., Brase, R., Lowry, S. F., Sadoff, J. C., Slotman, G. J., Levy, H., Balk, R. A., Shelly, M. P., Pribble, J. P., LaBrecque, J. F., Lookabaugh, J., Donovan, H., Dubin, H., Baughman, R., Norman, J., DeMaria, E., Matzel, K., Abraham, E., and Seneff, M. (1997). Confirmatory interleukin-1 receptor antagonist trial in severe sepsis: a phase III, randomized, double-blind, placebocontrolled, multicenter trial. The Interleukin-1 Receptor Antagonist Sepsis Investigator Group. Crit. Care Med. 25, 1115-1124.

Otterbein, L., Sylvester, S. L., and Choi, A. M. (1995). Hemoglobin provides protection against lethal endotoxemia in rats: the role of heme oxygenase-1. Am. J. Respir. Cell Mol. Biol. 13, 595-601.

Otterbein, L. E., Bach, F. H., Alam, J., Soares, M., Tao Lu, H., Wysk, M., Davis, R. J., Flavell, R. A., and Choi, A. M. (2000). Carbon monoxide has anti-inflammatory effects involving the mitogen-activated protein kinase pathway. Nat. Med. 6, 422-428.

Otterbein, L. E., Kolls, J. K., Mantell, L. L., Cook, J. L., Alam, J., and Choi, A. M. (1999a). Exogenous administration of heme oxygenase- 1 by gene transfer provides protection against hyperoxia-induced lung injury. $J$. Clin. Invest. 103, 1047-1054.

Otterbein, L. E., Mantell, L. L., and Choi, A. M. (1999b). Carbon monoxide provides protection against hyperoxic lung injury. Am. J. Physiol. 276(Pt 1), L688-L694.

Otterbein, L. E., Zuckerbraun, B. S., Haga, M., Liu, F., Song, R., Usheva, A., Stachulak, C., Bodyak, N., Smith, R. N., Csizmadia, E., Tyagi, S., Akamatsu, Y., Flavell, R. J., Billiar, T.
R., Tzeng, E., Bach, F. H., Choi, A. M., and Soares, M. P. (2003). Carbon monoxide suppresses arteriosclerotic lesions associated with chronic graft rejection and with balloon injury. Nat. Med. 9, 183-190.

Overhaus, M., Moore, B. A., Barbato, J. E., Behrendt, F. F., Doering, J. G., and Bauer, A. J. (2006). Biliverdin protects against polymicrobial sepsis by modulating inflammatory mediators. Am. J. Physiol. Gastrointest. Liver Physiol. 290, G695-G703.

Pamplona, A., Ferreira, A., Balla, J., Jeney, V., Balla, G., Epiphanio, S., Chora, A., Rodrigues, C. D., Gregoire, I. P., Cunha-Rodrigues, M., Portugal, S., Soares, M. P., and Mota, M. M. (2007). Heme oxygenase- 1 and carbon monoxide suppress the pathogenesis of experimental cerebral malaria. Nat. Med. 13, 703-710.

Paoli, M., Anderson, B. F., Baker, H. M., Morgan, W. T., Smith, A., and Baker, E. N. (1999). Crystal structure of hemopexin reveals a novel highaffinity heme site formed between two beta-propeller domains. Nat. Struct. Biol. 6, 926-931.

Paoli, M., Liddington, R., Tame, J., Wilkinson, A., and Dodson, G. (1996). Crystal structure of $\mathrm{T}$ state haemoglobin with oxygen bound at all four haems. J. Mol. Biol. 256, 775-792.

Park, S. Y., Yokoyama, T., Shibayama, N., Shiro, Y., and Tame, J. R. (2006). 1.25 A resolution crystal structures of human haemoglobin in the oxy, deoxy and carbonmonoxy forms. $J$. Mol. Biol. 360, 690-701.

Pauling, L., Itano, H. A., Singer, S. J., and Wells, I. C. (1949). Sickle cell anemia a molecular disease. Science 110, 543-548.

Pena, A. C., Penacho, N., Mancio-Silva, L., Neres, R., Seixas, J. D., Fernandes, A. C., Romao, C. C., Mota, M. M., Bernardes, G. J., and Pamplona, A. (2012). A novel carbon monoxidereleasing molecule (CO-RM) fully protects mice from severe malaria. Antimicrob. Agents Chemother. 56, 1281-1290.

Pham, C. G., Bubici, C., Zazzeroni, F., Papa, S., Jones, J., Alvarez, K., Jayawardena, S., De Smaele, E., Cong, R., Beaumont, C., Torti, F. M., Torti, S. V., and Franzoso, G. (2004). Ferritin heavy chain upregulation by NF-kappaB inhibits TNFalphainduced apoptosis by suppressing reactive oxygen species. Cell 119, 529-542.

Philippidis, P., Mason, J. C., Evans, B. J., Nadra, I., Taylor, K. M., Haskard, D. O., and Landis, R. C. (2004). Hemoglobin scavenger receptor CD163 mediates interleukin-10 release and heme oxygenase- 1 synthesis: antiinflammatory monocyte-macrophage responses in vitro, in resolving skin blisters in vivo, and after cardiopulmonary bypass surgery. Circ. Res. 94, 119-126.

Piagnerelli, M., Boudjeltia, K. Z., Vanhaeverbeek, M., and Vincent, J. L. (2003). Red blood cell rheology in sepsis. Intensive Care Med. 29, 1052-1061.

Piantadosi, C. A. (2008). Carbon monoxide, reactive oxygen signaling, and oxidative stress. Free Radic. Biol. Med. 45, 562-569.

Podstawka, E., and Proniewicz, L. M. (2004). Resonance Raman study of deoxy and ligated (O2 and $\mathrm{CO}$ ) mesoheme IX-reconstituted myoglobin, hemoglobin and its alpha and beta subunits. J. Inorg. Biochem. 98, 1502-1512.

Porto, B. N., Alves, L. S., Fernandez, P. L., Dutra, T. P., Figueiredo, R. T., Graca-Souza, A. V., and Bozza, M. T. (2007). Heme induces neutrophil migration and reactive oxygen species generation through signaling pathways characteristic of chemotactic receptors. J. Biol. Chem. 282, 24430-24436.

Poss, K. D., and Tonegawa, S. (1997a). Heme oxygenase 1 is required for mammalian iron reutilization. Proc. Natl. Acad. Sci. U.S.A. 94, 10919-10924.

Poss, K. D., and Tonegawa, S. (1997b). Reduced stress defense in heme oxygenase 1-deficient cells. Proc. Natl. Acad. Sci. U.S.A. 94, 10925-10930.

Poulos, T. L. (2007). The Janus nature of heme. Nat. Prod. Rep. 24, 504-510.

Putnam, C. D., Arvai, A. S., Bourne, Y., and Tainer, J. A. (2000). Active and inhibited human catalase structures: ligand and NADPH binding and catalytic mechanism. J. Mol. Biol. 296, 295-309.

Quaye, I. K. (2008). Haptoglobin, inflammation and disease. Trans. $R$. Soc. Trop. Med. Hyg. 102, 735-742.

Queiroga, C. S., Almeida, A. S., Martel, C., Brenner, C., Alves, P. M., and Vieira, H. L. (2010). Glutathionylation of adenine nucleotide translocase induced by carbon monoxide prevents mitochondrial membrane permeabilization and apoptosis. $J$. Biol. Chem. 285, 17077-17088.

Quigley, J. G., Burns, C. C., Anderson, M. M., Lynch, E. D., Sabo, K. M., Overbaugh, J., and Abkowitz, J. L. (2000). Cloning of the cellular receptor for feline leukemia virus subgroup C (FeLV-C), a retrovirus that induces red cell aplasia. Blood 95, 1093-1099.
Quigley, J. G., Yang, Z., Worthington, M. T., Phillips, J. D., Sabo, K. M., Sabath, D. E., Berg, C. L., Sassa, S., Wood, B. L., and Abkowitz, J. L. (2004). Identification of a human heme exporter that is essential for erythropoiesis. Cell 118, 757-766.

Rajagopal, A., Rao, A. U., Amigo, J., Tian, M., Upadhyay, S. K., Hall, C., Uhm, S., Mathew, M. K., Fleming, M. D., Paw, B. H., Krause, M., and Hamza, I. (2008). Haem homeostasis is regulated by the conserved and concerted functions of HRG-1 proteins. Nature 453, 1127-1131.

Reedy, C. J., and Gibney, B. R. (2004). Heme protein assemblies. Chem. Rev. 104, 617-649.

Reiter, C. D., Wang, X., Tanus-Santos, J. E., Hogg, N., Cannon, R. O. III, Schechter, A. N., and Gladwin, M. T. (2002). Cell-free hemoglobin limits nitric oxide bioavailability in sicklecell disease. Nat. Med. 8, 1383-1389.

Riedemann, N. C., Guo, R. F., and Ward, P. A. (2003). Novel strategies for the treatment of sepsis. Nat. Med. 9, 517-524.

Rittirsch, D., Huber-Lang, M. S., Flierl, M. A., and Ward, P. A. (2009) Immunodesign of experimental sepsis by cecal ligation and puncture. Nat. Protoc. 4, 31-36.

Rosenthal, P. J. (2011). Lessons from sickle cell disease in the treatment and control of malaria. N. Engl. J. Med. 364, 2549-2551.

Rother, R. P., Bell, L., Hillmen, P., and Gladwin, M. T. (2005). The clinical sequelae of intravascular hemolysis and extracellular plasma hemoglobin: a novel mechanism of human disease. JAMA 293, 1653-1662.

Rowland, P., Blaney, F. E., Smyth, M. G., Jones, J. J., Leydon, V. R., Oxbrow, A. K., Lewis, C. J., Tennant, M. G., Modi, S., Eggleston, D. S., Chenery, R. J., and Bridges, A. M. (2006). Crystal structure of human cytochrome P450 2D6. J. Biol. Chem. 281, 7614-7622.

Sambo, M. R., Trovoada, M. J., Benchimol, C., Quinhentos, V., Goncalves L., Velosa, R., Marques, M. I., Sepulveda, N., Clark, T. G., Mustafa, S., Wagner, O., Coutinho, A., and Penha-Goncalves, C. (2010). Transforming growth factor beta 2 and heme oxygenase 1 genes are risk factors for the cerebral malaria syndrome in Angolan children. PLoS ONE 5, el1141. doi:10.1371/journal.pone.0011141

Sanchez-Perez, I., Martinez-Gomariz, M., Williams, D., Keyse, S. M. and Perona, R. (2000). CL100/MKP1 modulates JNK activation and 
apoptosis in response to cisplatin. Oncogene 19, 5142-5152.

Sarady-Andrews, J. K., Liu, F., Gallo, D., Nakao, A., Overhaus, M., Ollinger, R., Choi, A. M., and Otterbein, L. E. (2005). Biliverdin administration protects against endotoxin-induced acute lung injury in rats. Am. J. Physiol. Lung Cell Mol. Physiol. 289, L1131-L1137.

Sato, K., Balla, J., Otterbein, L., Smith, R. N., Brouard, S., Lin, Y., Csizmadia, E., Sevigny, J., Robson, S. C., Vercellotti, G., Choi, A. M., Bach, F. H., and Soares, M. P. (2001). Carbon monoxide generated by heme oxygenase-1 suppresses the rejection of mouse-to-rat cardiac transplants. J. Immunol. 166, 4185-4194.

Schaefer, W. H., Harris, T. M., and Guengerich, F. P. (1985). Characterization of the enzymatic and nonenzymatic peroxidative degradation of iron porphyrins and cytochrome P-450 heme. Biochemistry 24, 3254-3263.

Schneider, S., Marles-Wright, J., Sharp, K. H., and Paoli, M. (2007). Diversity and conservation of interactions for binding heme in b-type heme proteins. Nat. Prod. Rep. 24, 621-630.

Schultz, I. J., Chen, C., Paw, B. H., and Hamza, I. (2010). Iron and porphyrin trafficking in heme biogenesis. J. Biol. Chem. 285, 26753-26759.

Seixas, E., Gozzelino, R., Chora, A., Ferreira, A., Silva, G., Larsen, R., Rebelo, S., Penido, C., Smith, N. R., Coutinho, A., and Soares, M. P. (2009). Heme oxygenase1 affords protection against noncerebral forms of severe malaria. Proc. Natl. Acad. Sci. U.S.A. 106, 15837-15842.

Seldon, M. P., Silva, G., Pejanovic, N., Larsen, R., Gregoire, I. P., Filipe, J., Anrather, J., and Soares, M. P. (2007). Heme oxygenase-1 inhibits the expression of adhesion molecules associated with endothelial cell activation via inhibition of NF-kappaB RelA phosphorylation at serine 276. J. Immunol. 179, 7840-7851.

Shayeghi, M., Latunde-Dada, G. O., Oakhill, J. S., Laftah, A. H., Takeuchi, K., Halliday, N., Khan, Y., Warley, A., McCann, F. E., Hider, R. C., Frazer, D. M., Anderson, G. J., Vulpe, C. D., Simpson, R. J., and McKie, A. T. (2005). Identification of an intestinal heme transporter. Cell 122, 789-801.

Shen, X. D., Ke, B., Zhai, Y., Gao, F., Busuttil, R. W., Cheng, G., and Kupiec-Weglinski, J. W. (2005). Toll-like receptor and heme oxygenase-1 signaling in hepatic ischemia/reperfusion injury. Am. J. Transplant. 5, 1793-1800.

Sil, S., Bose, T., Roy, D., and Chakraborti, A. S. (2004). Protoporphyrin IXinduced structural and functional changes in human red blood cells, haemoglobin and myoglobin. $J$. Biosci. 29, 281-291.

Silva, G., Cunha, A., Gregoire, I. P., Seldon, M. P., and Soares, M. P. (2006). The antiapoptotic effect of heme oxygenase-1 in endothelial cells involves the degradation of $\mathrm{p} 38$ alpha MAPK isoform. J. Immunol. 177, 1894-1903.

Silva, G., Jeney, V., Chora, A., Larsen, R., Balla, J., and Soares, M. P. (2009). Oxidized hemoglobin is an endogenous proinflammatory agonist that targets vascular endothelial cells. $J$. Biol. Chem. 284, 29582-29595.

Singleton, J. W., and Laster, L. (1965). Biliverdin reductase of guinea pig liver. J. Biol. Chem. 240, 4780-4789.

Smith, L. J., Kahraman, A., and Thornton, J. M. (2010). Heme proteinsdiversity in structural characteristics, function, and folding. Proteins 78, 2349-2368.

Soares, M. P., and Bach, F. H. (2007). Heme oxygenase-1 in organ transplantation. Front. Biosci. 12, 4932-4945.

Soares, M. P., Lin, Y., Anrather, J., Csizmadia, E., Takigami, K., Sato, K., Grey, S. T., Colvin, R. B., Choi, A. M., Poss, K. D., and Bach, F. H. (1998). Expression of heme oxygenase-1 can determine cardiac xenograft survival. Nat. Med. 4, 1073-1077.

Soares, M. P., Lin, Y., Sato, K., Stuhlmeier, K. M., and Bach, F. H. (1999). Accommodation. Immunol. Today 20, 434-437.

Soares, M. P., Seldon, M. P., Gregoire, I. P., Vassilevskaia, T., Berberat, P. O., Yu, J., Tsui, T. Y., and Bach, F. H. (2004). Heme oxygenase-1 modulates the expression of adhesion molecules associated with endothelial cell activation. J. Immunol. 172, 3553-3563.

Sollwedel, A., Bertoja, A. Z., Zenclussen, M. L., Gerlof, K., Lisewski, U., Wafula, P., Sawitzki, B., Woiciechowsky, C., Volk, H. D., and Zenclussen, A. C. (2005). Protection from abortion by heme oxygenase-1 up-regulation is associated with increased levels of Bag-1 and neuropilin-1 at the fetal-maternal interface. J. Immunol. 175, 4875-4885.

Stocker, R., and Perrella, M. A. (2006). Heme oxygenase-1: a novel drug target for atherosclerotic diseases? Circulation 114, 2178-2189.
Stocker, R., Yamamoto, Y., McDonagh, A. F., Glazer, A. N., and Ames, B. N. (1987). Bilirubin is an antioxidant of possible physiological importance. Science 235, 1043-1046.

Sugimoto, H., Oda, S., Otsuki, T., Hino, T., Yoshida, T., and Shiro, Y. (2006). Crystal structure of human indoleamine 2,3-dioxygenase: catalytic mechanism of $\mathrm{O} 2$ incorporation by a heme-containing dioxygenase. Proc. Natl. Acad. Sci. U.S.A. 103, 2611-2616.

Szatmari, I., Vamosi, G., Brazda, P., Balint, B. L., Benko, S., Szeles, L., Jeney, V., Ozvegy-Laczka, C., Szanto, A., Barta, E., Balla, J., Sarkadi, B., and Nagy, L. (2006). Peroxisome proliferatoractivated receptor gamma-regulated ABCG2 expression confers cytoprotection to human dendritic cells. $J$. Biol. Chem. 281, 23812-23823.

Tahara, S. M., Traugh, J. A., Sharp, S. B., Lundak, T. S., Safer, B., and Merrick, W. C. (1978). Effect of hemin on site-specific phosphorylation of eukaryotic initiation factor 2. Proc Natl. Acad. Sci. U.S.A. 75, 789-793.

Tahara, T., Sun, J., Igarashi, K., and Taketani, S. (2004a). Heme-dependent up-regulation of the alpha-globin gene expression by transcriptional repressor Bach1 in erythroid cells. Biochem. Biophys. Res. Commun. 324, 77-85.

Tahara, T., Sun, J., Nakanishi, K. Yamamoto, M., Mori, H., Saito, T., Fujita, H., Igarashi, K., and Taketani, S. (2004b). Heme positively regulates the expression of beta-globin at the locus control region via the transcriptional factor Bach 1 in erythroid cells. J. Biol. Chem. 279, 5480-5487.

Tang, X. D., Xu, R., Reynolds, M. F., Garcia, M. L., Heinemann, S. H., and Hoshi, T. (2003). Haem can bind to and inhibit mammalian calciumdependent Slol BK channels. Nature 425, 531-535

Tanoue, T., Yamamoto, T., Maeda, R., and Nishida, E. (2001). A Novel MAPK phosphatase MKP-7 acts preferentially on JNK/SAPK and p38 alpha and beta MAPKs. J. Biol. Chem. 276, 26629-26639.

Tenhunen, R., Marver, H. S., and Schmid, R. (1968). The enzymatic conversion of heme to bilirubin by microsomal heme oxygenase. Proc. Natl. Acad. Sci. U.S.A. 61, 748-755.

Tolosano, E., Fagoonee, S., Morello, N. Vinchi, F., and Fiorito, V. (2010). Heme scavenging and the other facets of hemopexin. Antioxid. Redox Signal. 12, 305-320.

Tolosano, E., Hirsch, E., Patrucco, E., Camaschella, C., Navone, R., Silengo,
L., and Altruda, F. (1999). Defective recovery and severe renal damage after acute hemolysis in hemopexindeficient mice. Blood 94, 3906-3914.

Trakshel, G. M., Kutty, R. K., and Maines, M. D. (1986). Purification and characterization of the major constitutive form of testicular heme oxygenase. The noninducible isoform. J. Biol. Chem. 261, 11131-11137.

Tsiftsoglou, A. S., Tsamadou, A. I., and Papadopoulou, L. C. (2006) Heme as key regulator of major mammalian cellular functions: molecular, cellular, and pharmacological aspects. Pharmacol. Ther. 111, 327-345.

Tsukihara, T., Aoyama, H., Yamashita, E., Tomizaki, T., Yamaguchi, H., Shinzawa-Itoh, K., Nakashima, R., Yaono, R., and Yoshikawa, S. (1995). Structures of metal sites of oxidized bovine heart cytochrome $\mathrm{c}$ oxidase at 2.8 A. Science 269, 1069-1074.

Tzima, S., Victoratos, P., Kranidioti, K., Alexiou, M., and Kollias, G. (2009). Myeloid heme oxygenase-1 regulates innate immunity and autoimmunity by modulating IFN-beta production. J. Exp. Med. 206, 1167-1179.

Uchida, T., Sato, E., Sato, A., Sagami, I., Shimizu, T., and Kitagawa, T. (2005). CO-dependent activitycontrolling mechanism of hemecontaining CO-sensor protein, neuronal PAS domain protein 2. J. Biol. Chem. 280, 21358-21368.

Ulloa, L., and Tracey, K. J. (2005). The "cytokine profile": a code for sepsis. Trends. Mol. Med. 11, 56-63.

Ventura, J. J., Cogswell, P., Flavell, R. A., Baldwin, A. S. Jr., and Davis, R. J. (2004). JNK potentiates TNFstimulated necrosis by increasing the production of cytotoxic reactive oxygen species. Genes Dev. 18, 2905-2915.

Vile, G. F., Basu-Modak, S., Waltner, C., and Tyrrell, R. M. (1994). Heme oxygenase 1 mediates an adaptive response to oxidative stress in human skin fibroblasts. Proc. Natl. Acad. Sci. U.S.A. 91, 2607-2610.

Vojtechovsky, J., Chu, K., Berendzen, J., Sweet, R. M., and Schlichting, I. (1999). Crystal structures of myoglobin-ligand complexes at near-atomic resolution. Biophys. J. 77, 2153-2174

Walther, M., De Caul, A., Aka, P., Njie, M., Amambua-Ngwa, A., Walther, B., Predazzi, I. M., Cunnington, A. Deininger, S., Takem, E. N., Ebonyi, A., Weis, S., Walton, R., RowlandJones, S., Sirugo, G., Williams, S. M., and Conway, D. J. (2012). HMOX1 gene promoter alleles and 
high HO-1 levels are associated with severe malaria in Gambian children. PLoS Pathog. 8, e1002579. doi:10.1371/journal.ppat.1002579

Wang, H., Lee, S. S., Dell'Agnello, C., Tchipashvili, V., d'Avila, J. C., Czismadia, E., Chin, B. Y., and Bach, F. H. (2006). Bilirubin can induce tolerance to islet allografts. Endocrinology $147,762-768$.

Wang, X., Wang, Y., Lee, S. J., Kim, H. P., Choi, A. M., and Ryter, S. W. (2011). Carbon monoxide inhibits Fas activating antibody-induced apoptosis in endothelial cells. Med. Gas Res. 1,8 .

Wardell, M., Wang, Z., Ho, J. X., Robert, J., Ruker, F., Ruble, J., and Carter, D. C. (2002). The atomic structure of human methemalbumin at 1.9 A. Biochem. Biophys. Res. Commun. 291, 813-819.

Williams, T. N., Mwangi, T. W., Roberts, D. J., Alexander, N. D., Weatherall, D. J., Wambua, S., Kortok, M., Snow, R. W., and Marsh, K. (2005a). An immune basis for malaria protection by the sickle cell trait. PLoS Med. 2, e128. doi:10.1371/journal.pmed.0020128

Williams, T. N., Mwangi, T. W., Wambua, S., Alexander, N. D., Kortok, M., Snow, R. W., and Marsh, K. (2005b). Sickle cell trait and the risk of Plasmodium falciparum malaria and other childhood diseases. $J$. Infect. Dis. 192, 178-186.

Wirtz, M., Oganesyan, V., Zhang, X., Studer, J., and Rivera, M. (2000). Modulation of redox potential in electron transfer proteins: effects of complex formation on the active site microenvironment of cytochrome b5. Faraday Discuss. 221-234; discussion 257-268.

Xia, D., Yu, C. A., Kim, H., Xia, J. Z., Kachurin, A. M., Zhang, L., Yu, L., and Deisenhofer, J. (1997). Crystal structure of the cytochrome bcl complex from bovine heart mitochondria. Science 277, 60-66.

Xie, C., Zhang, N., Zhou, H., Li, J., Li, Q., Zarubin, T., Lin, S. C., and Han, J. (2005). Distinct roles of basal steady-state and induced $\mathrm{H}$-ferritin in tumor necrosis factor-induced death in L929 cells. Mol. Cell. Biol. 25, 6673-6681.

Yamashita, K., McDaid, J., Ollinger, R., Tsui, T. Y., Berberat, P. O., Usheva, A., Csizmadia, E., Smith, R. N., Soares, M. P., and Bach, F. H. (2004). Biliverdin, a natural product of heme catabolism, induces tolerance to cardiac allografts. FASEB J. 18 , 765-767.

Yet, S. F., Layne, M. D., Liu, X., Chen, Y. H., Ith, B., Sibinga, N. E., and Perrella, M. A. (2003). Absence of heme oxygenase- 1 exacerbates atherosclerotic lesion formation and vascular remodeling. FASEB J. 17, 1759-1761.

Yet, S. F., Perrella, M. A., Layne, M. D., Hsieh, C. M., Maemura, K., Kobzik, L., Wiesel, P., Christou, H., Kourembanas, S., and Lee, M. E. (1999). Hypoxia induces severe right ventricular dilatation and infarction in heme oxygenase-1 null mice. J. Clin. Invest. 103, R23-R29.

Youn, H., Conrad, M., Chung, S. Y., and Roberts, G. P. (2006). Roles of the heme and heme ligands in the activation of CooA, the CO-sensing transcriptional activator. Biochem. Biophys. Res. Commun. 348, 345-350.

Zederbauer, M., Furtmuller, P. G., Brogioni, S., Jakopitsch, C., Smulevich, G., and Obinger, C. (2007). Heme to protein linkages in mammalian peroxidases: impact on spectroscopic, redox and catalytic properties. Nat. Prod. Rep. 24, 571-584.
Zenclussen, A. C., Lim, E., Knoeller, S. Knackstedt, M., Hertwig, K., Hagen, E., Klapp, B. F., and Arck, P. C. (2003). Heme oxygenases in pregnancy II: HO-2 is downregulated in human pathologic pregnancies. Am. J. Reprod. Immunol. 50, 66-76.

Zenclussen, A. C., Sollwedel, A., Bertoja, A. Z., Gerlof, K., Zenclussen, M. L., Woiciechowsky, C., and Volk, H. D. (2005). Heme oxygenase as a therapeutic target in immunological pregnancy complications. Int Immunopharmacol. 5, 41-51.

Zenclussen, M. L., Casalis, P. A., ElMousleh, T., Rebelo, S., Langwisch, S., Linzke, N., Volk, H. D., Fest, S. Soares, M. P., and Zenclussen, A. C. (2011). Haem oxygenase-1 dictates intrauterine fetal survival in mice via carbon monoxide. J. Pathol. 225 293-304.

Zenke-Kawasaki, Y., Dohi, Y., Katoh, Y., Ikura, T., Ikura, M., Asahara, T., Tokunaga, F., Iwai, K., and Igarashi, K. (2007). Heme induces ubiquitination and degradation of the transcription factor Bach1. Mol. Cell. Biol. 27, 6962-6971.

Zhang, W., Wang, M., Xie, H. Y., Zhou, L., Meng, X. Q., Shi, J., and Zheng, S. (2007a). Role of reactive oxygen species in mediating hepatic ischemia-reperfusion injury and its therapeutic applications in liver transplantation. Transplant. Proc. 39, 1332-1337.

Zhang, Y., Kang, S. A., Mukherjee, T., Bale, S., Crane, B. R., Begley, T. P., and Ealick, S. E. (2007b). Crystal structure and mechanism of tryptophan 2,3-dioxygenase, a heme enzyme involved in tryptophan catabolism and in quinolinate biosynthesis. Biochemistry 46, 145-155.

Zhang, Z., Huang, L., Shulmeister, V. M., Chi, Y. I., Kim, K. K., Hung,
L. W., Crofts, A. R., Berry, E. A., and Kim, S. H. (1998). Electron transfer by domain movement in cytochrome bcl. Nature 392, 677-684.

Zhu, Y., Lee, H. C., and Zhang, L. (2002a). An examination of heme action in gene expression: heme and heme deficiency affect the expression of diverse genes in erythroid $\mathrm{k} 562$ and neuronal PC12 cells. DNA Cell Biol. 21, 333-346.

Zhu, Y., Sun, Y., Jin, K., and Greenberg, D. A. (2002b). Hemin induces neuroglobin expression in neural cells. Blood 100, 2494-2498.

Conflict of Interest Statement: The authors declare that the research was conducted in the absence of any commercial or financial relationships that could be construed as a potential conflict of interest.

Received: 10 February 2012; paper pending published: 25 February 2012; accepted: 11 April 2012; published online: 04 May 2012

Citation: Larsen R, Gouveia Z, Soares MP and Gozzelino R (2012) Heme cytotoxicity and the pathogenesis of immune-mediated inflammatory diseases. Front. Pharmacol. 3:77. doi: 10.3389/fphar.2012.00077

This article was submitted to Frontiers in Drug Metabolism and Transport, a specialty of Frontiers in Pharmacology. Copyright (c) 2012 Larsen, Gouveia, Soares and Gozzelino. This is an openaccess article distributed under the terms of the Creative Commons Attribution Non Commercial License, which permits non-commercial use, distribution, and reproduction in other forums, provided the original authors and source are credited. 